\title{
Political Rights and the Cost of Debt
}

\author{
February 6, 2008
}

\begin{abstract}
We examine the impact of country-level political rights on the cost of debt for a large sample of corporate bonds issued by firms incorporated in 39 countries. Similar to, but separate from, the relation for creditor rights, greater political rights are associated with higher bond ratings and lower yield spreads. A one standard deviation increase in political rights is associated with an $18.6 \%$ decline in bond spreads. We find evidence that political and legal institutions are substitutes; marginal improvements in political rights produce greater reductions in the cost of debt for firms from countries with weaker creditor rights. We examine potential factors through which political rights may affect the cost of debt and find that greater freedom of the press provides an important channel for reducing bond risks, although corruption and expropriation risks also matter. Moreover, debt of firms with cross-listed equity trades at a premium in U.S. markets, but this relation appears to be more consistent with improved visibility (Merton, 1987) than with bonding effects.
\end{abstract}

Keywords: Legal institutions, Political institutions, Cost of debt

JEL classification: G20, F59, K22 


\section{Introduction}

A variety of country characteristics, such as political and legal institutions, can impact financial development and affect the ease with which firms raise capital. We extend the existing literature by considering the joint impact of country-level political institutions and legal institutions in determining a firm's cost of external debt finance. ${ }^{1}$ In particular, we study (i) the relative importance of political institutions and legal institutions in credit markets; (ii) whether political and legal institutions function as substitutes, complements, or independent factors; (iii) the underlying channels through which political rights may impact credit markets; and (iv) whether cross-listing equity helps reduce the cost of debt. Our study is related to Roe (2006) and Roe and Siegel (2007) in that we also emphasize the role of political institutions, but we differ in that we use firm-level data to estimate the impact of political and legal institutions on firms’ cost of debt, while they focus on various country-level effects.

A recent strand of empirical studies in law and finance suggests that differences in legal origin and legal institutions help explain cross-country differences in financial development and economic growth. Seminal works by La Porta, Lopez-de-Silanes, Shleifer and Vishny (hereafter LLSV (1997 and 1998)) suggest that legal systems with common law origins offer better protection to creditors and shareholders, and hence provide a better environment for financial market development, than civil-law origins. Subsequent research focuses on legal institutions as well as on legal origins. These studies address the impact of legal institutions on corporate governance (LLSV (2000)); corporate valuations (LLSV (2002)); firms’ external finance and

\footnotetext{
${ }^{1}$ Our primary measure of political institutions is an index of political rights provided by Freedom House (see also LLSV (1999)). Higher index values reflect free and fair elections, that those elected rule, the existence of competitive parties or other competitive political groupings, that the opposition has an important role and power, and that entities have self-determination or an extremely high degree of autonomy. Or main measure for legal institutions is a creditor rights index, which measure to what degree creditors are protected in a country (see also Djankov, McLiesh, and Shleifer (2007) and LLSV (1998)). We also control for legal origin in our analysis and use a battery of alternative measures for political institutions and legal institutions for robustness.
} 
growth (Demirguc-Kunt and Maksimovic (1998)); firms' debt maturity structures (DemirgucKunt and Maksimovic (1999)); development of private credit markets (Djankov, McLiesh, and Shleifer (2007)); and bank loan terms (Qian and Strahan (2007)). In addition, Levine (1999) shows that legal institutions and legal origins influence economic growth by shaping the national financial system. Beck, Demirguc-Kunt, and Levine (2003) consider the relative importance of legal origins and the natural endowment in explaining financial development.

However, some scholars argue that our understanding of how legal institutions impact financial development and economic growth may be incomplete (see, for instance, Coffee (2001), Rajan and Zingales (2003), Roe (2006), and Milhaupt and Pistor (2007)). One view is that legal origins/institutions and their enforcement are largely determined by a country's political institutions, and that this political factor is missed or neglected in much of the current law and finance theory. In contrast to LLSV (1997 and 1998), Rajan and Zingales (2003) find that financial markets in civil-law nations were as well developed as those in common-law nations in 1913. They propose that the ability of interest groups to affect policies is mitigated by trade and legal institutions and that this bargaining process is the most important determinant of financial market growth. Roe (2006) further develops this political argument. He suggests that political economy and political history are more important than legal origin in explaining differences in financial development across countries. Empirically, Roe and Siegel (2007) show that political instability is a primary determinant of financial development. In addition, Haber (2005) argues that political rather than legal factors were more important in the development of the U.S. and Mexican banking systems up to 1913, whereas Allen, Qian and Qian (2005) show that China is a counterexample to the law-finance-growth argument and argue for the importance 
of an informal financial system. All of these findings open the possibility of evaluating factors other than legal institutions to explain financial development and economic growth. ${ }^{2}$

In our analysis, we use a large sample of international corporate bonds to study the impact of country-level political institutions on the firm's cost of debt. Bonds are a natural instrument to study the impact of political and legal factors as yields incorporate an ex-ante view of risks and returns, whereas stock returns are only measured ex-post and thus reflect greater noise from unforeseen events. Corporate bonds reflect a simple borrowing-lending contractual relationship. Hence, the implied value of the cash flows associated with a bond contract is likely to be affected by the country's political stability and creditor protection laws. Since debt markets are an important conduit for the availability of capital, policies or institutions that lower the cost of debt capital can facilitate greater economic activity.

Our main interest is the impact of political institutions, as measured primarily by political rights, on the cost of debt, as captured by bond ratings and spreads. We consider U.S. dollar denominated corporate Eurobonds from firms in 39 countries, and for robustness, we check our results with a separate sample of foreign corporate bonds issued in the U.S. bond market (hereafter: Yankee bonds). In all our analyses, we control for legal institutions as well as firm characteristics and bond characteristics (in robustness tests, we also control for legal origins). ${ }^{3}$ We find that a one standard deviation increase in political rights implies an increase of approximately half a Standard \& Poors' rating level. This change is similar to the ratings change from a one standard deviation increase in creditor rights. In terms of bond spreads over

\footnotetext{
${ }^{2}$ The idea that political rights can decrease investor risk has also been mentioned in the media. For instance, Frum (2007) says, "Democracy is not only the freest and fairest form of government. It is also the best protection against downside investor risk."

${ }^{3}$ Note that political rights and legal institutions have a low correlation but they are both highly correlated with bond ratings and bond spreads. For example, China has the lowest average political rights of the countries in our sample with a score of 1 , but China has a creditor rights rating of 2 . France on the other hand rates a 7 in political rights but a 0 on creditor rights. The findings suggest that political and legal institutions capture different impacts upon the financial system.
} 
treasuries, a one standard deviation increase in political rights implies an $18.6 \%$ decrease in spreads on average, whereas a one standard deviation increase in creditor rights implies a decrease in spreads of $12.9 \%$. Sovereign ratings could capture the full impact of political or creditor rights on bond spreads, but our empirical results suggest that sovereign ratings typically encapsulate only a small portion of these effects. ${ }^{4}$ Political rights have a significant impact on the firm's cost of debt even after controlling for country legal institutions, sovereign ratings, and other country-level variables.

We also test whether political and legal institutions are substitutes or complements with respect to a firm's cost of debt. Thus, we add the interaction between political and legal institution to our benchmark model. Our empirical results suggest that legal and political institutions are substitutes in determining the cost of debt. Specifically, marginal improvements in political institutions produce greater reductions to the cost of debt for firms from weak legal systems than those from well-developed legal systems. Similarly, the impact of legal institutions in reducing cost of debt is larger for firms from poor political systems than for those from more developed political systems. This finding is consistent with models presented by Djankov, Glaeser, La Porta, Lopez-de-Silanes and Shleifer (2003) and Glaeser and Shleifer (2003).

We further examine potential channels through which political rights might affect credit markets. We add variables which measure the socio-political instability, freedom of the press, corruption, and expropriation risk as possible explanations for the impact of political institutions on corporate bonds. Adding these variables does not eliminate the impact of political rights, but if political rights are excluded, freedom of the press appears to capture some of the same effects as our political rights variable. Thus, countries with better political rights may provide greater

\footnotetext{
${ }^{4}$ For more on sovereign ratings see Cantor and Packer (1996a and 1996b), Kaminsky and Schmukler (2002), and Gande and Parsley (2007).
} 
freedom of the press, which may in turn improve information acquisition. This improved information availability appears to be associated with a reduction in the firm's cost of debt.

Our final question is related to the issue of how cross-listing equity impacts debt value. On the one hand, a number of authors (Fuerst (1998), Stulz (1999), and Coffee (1999)) hypothesize that firm value is increased by bonding to a stricter set of laws and standards. On the other hand, Siegel (2005) suggests that cross-listing does not bond the firm but that it provides an increase in reputation. We therefore examine whether cross-listed equity helps increase debt value, and whether this is related to differences between the legal rights of the home and cross-listed country. We find that cross-listing equity has a positive impact on debt for the corporate Yankee bond market but there is no impact on corporate Eurobonds. The evidence is more supportive of improved visibility decreasing debt yields, consistent with Merton’s (1987) investor recognition hypothesis, than of a bonding effect.

Our findings have broad implications for firms, governments, and policymakers. Our results suggest that political institutions can significantly impact firms' cost of capital, and this in turn could create greater opportunities for investment and economic growth with improving political, as well as legal, regimes.

The rest of the paper is organized as follows. Section II discusses the theoretical framework and specifies the hypotheses we test in greater detail. Section III details the data and empirical method. Section VI presents the empirical results, and Section V concludes.

\section{Hypotheses}

A number of theoretical researchers emphasize the importance of jointly considering the effects of political and legal institutions on financial development and economic growth. Whereas LLSV (1997 and 1998) emphasize that legal origins are the primary determinant in 
explaining cross-country differences in financial development and economic growth, Glaeser and Shleifer (2002) suggest that the initial design of common-law and civil-law origin is an adaptive product of the historical and political environment. Glaeser and Shleifer study the English Law (i.e., common-law origin) and French Law (i.e. civil-law origin) in the $12^{\text {th }}$ and $13^{\text {th }}$ centuries, and they suggest that the differences between English and French law are influenced by the political environments of that period. Specifically, the relatively more peaceful England develops a jury system with trial while the relatively more turbulent France relies on stateemployed judges to support legal enforcement. Milhaupt and Pistor (2007) also emphasize that "law, a product of human interaction, obviously does not function independently of the political system." They point out that "the political economy is crucial to the formation and the change of legal systems in a way that has not been developed in the literature: the political economy determines whether law is contestable.”

Djankov, Glaeser, La Porta, Lopez-de-Silanes, and Shleifer (2003) argue that one must consider a variety of institutions and their respective social costs when comparing the performance of different economic systems. They develop the concept of an institutional possibility frontier suggesting that the optimal structure of efficient institutions should balance the tradeoff between controlling for private disorder (e.g. development of private property protection) and controlling for dictatorship (e.g. development of democracy).

Given the significant body of empirical work documenting the importance of the legal system in financial development, and the nascent work addressing the political system, it is interesting to examine the joint impact of these two types of institutions on corporate credit markets. To this end, we conduct tests to answer the following issues. ${ }^{5}$

\footnotetext{
${ }^{5}$ We are aware that in the long run both legal and political institutions may undergo a variety of changes, and that it may be more productive to view the relationship between legal and political systems as an iterative process of
} 
The first question we examine is whether political rights have an impact on bond ratings and spreads after controlling for legal institutions. We use regression analysis to test this question. The dependent variables, bond rating and log bond yield spread, are regressed on variables describing political and legal institutions, country-level variables, firm-level measures, and bond characteristics. In particular, we consider the following two regression specifications:

$$
\begin{aligned}
\text { Bond rating }_{\mathrm{i}, \mathrm{t}}= & \gamma_{0}+\gamma_{1} \text { Political institutions }_{\mathrm{i}, \mathrm{t}}+\gamma_{2} \text { Legal institutions }_{\mathrm{i}, \mathrm{t}} \\
& +\beta^{\prime} \text { Controls }_{\mathrm{i}, \mathrm{t}}+\varepsilon_{\mathrm{i}, \mathrm{t}},
\end{aligned}
$$

$$
\begin{aligned}
\text { Yield spread }_{\mathrm{i}, \mathrm{t}}= & \gamma_{0}+\gamma_{1} \text { Political institutions }_{\mathrm{i}, \mathrm{t}}+\gamma_{2} \text { Legal institutions }_{\mathrm{i}, \mathrm{t}} \\
& +\beta^{\prime} \text { Controls }_{\mathrm{i}, \mathrm{t}}+\varepsilon_{\mathrm{i}, \mathrm{t}},
\end{aligned}
$$

where i identifies a particular bond issue, and t denotes the time of the bond issue. Our controls include country-level, firm-level, and bond-level characteristics. Our primary measure of political institutions is a political rights index and our primary measure of legal institutions is a creditor rights index (although we consider a number of alternative definitions for robustness). Definitions of these two variables, alternative measures of legal and political institutions, and the selection of control variables are discussed in detail in the next section.

The literature suggests that legal institutions help reduce the cost of a firm's external capital (Qian and Strahan (2007) and Demirguc-Kunt and Maksimovic (1998)). Consequently, we expect that better developed legal institutions help increase the bond rating and reduce the bond yield spread. Hence, we expect that $\gamma_{2}$ is positive in equation (1) and negative in equation (2). As suggested in Roe (2006) and Roe and Siegel (2007), political institutions and political

institutional evolution. However, examining changes in legal and political systems is beyond the scope of this paper. The framework presented in this paper is not able to test the long-run impact of how political rights impact legal development or vice versa. However, we are able to test the degree to which political and legal rights are priced by credit markets and therefore deepen our understanding of the roles of political and legal institutions in financial development and economic growth. 
stability are important in shaping a country's financial development. ${ }^{6}$ We therefore postulate that improved political institutions also imply higher bond ratings and lower yield spreads. Thus, we expect a significant positive $\gamma_{1}$ in equation (1) and a significant negative $\gamma_{1}$ in equation (2). Alternatively, if legal variables are sufficient to capture the institutional environment, political institutions will not have any additional explanatory power. In this case, the $\gamma_{1}$ coefficients will not be significant. Additionally, we are interested in the relative magnitudes of the coefficients on political and creditor rights to determine which is economically more significant.

Our second question is whether political rights and legal rights are complements, substitutes, or roughly independent from the point of view of credit markets. We examine the interaction between political rights and legal institutions with the following model:

$$
\begin{aligned}
\text { Bond rating }_{\mathrm{i}, \mathrm{t}}= & \gamma_{0}+\gamma_{1_{1}} \text { Political institutions }_{\mathrm{i}, \mathrm{t}}+\gamma_{2} \text { Legal institutions }_{\mathrm{i}, \mathrm{t}} \\
& +\gamma_{3}\left(\text { Political institutions }_{\mathrm{i}, \mathrm{t}} \times \text { Legal institutions }_{\mathrm{i}, \mathrm{t}}\right)+\beta^{\prime} \text { Controls }_{\mathrm{i}, \mathrm{t}}+\varepsilon_{\mathrm{i}, \mathrm{t}}, \\
\text { Yield spread }_{\mathrm{i}, \mathrm{t}}= & \gamma_{0}+\gamma_{1} \text { Political institutions }_{\mathrm{i}, \mathrm{t}}+\gamma_{2} \text { Legal institutions }_{\mathrm{i}, \mathrm{t}} \\
& +\gamma_{3}\left(\text { Political institutions }_{\mathrm{i}, \mathrm{t}} \times \text { Legal institutions }_{\mathrm{i}, \mathrm{t}}\right)+\beta^{\prime} \text { Controls }_{\mathrm{i}, \mathrm{t}}+\varepsilon_{\mathrm{i}, \mathrm{t}} \cdot
\end{aligned}
$$

A positive (negative) $\gamma_{3}$ in equation (4) indicates that political rights substitute (complement) for legal institutions. In this case, a marginal improvement in political institutions will cause a smaller (greater) reduction in the cost of debt if the firm is from a country with better legal institutions. An insignificant $\gamma_{3}$ suggests that the impacts of political and legal institutions are independent. A similar interpretation holds for equation (3), although the direction of the effect

\footnotetext{
${ }^{6}$ Additionally, Click (2005) finds that for foreign direct investment at the country level, higher country political risk is compensated for with higher ROA.
} 
is reversed. Namely, a negative $\gamma_{3}$ coefficient in equation (3) is associated with a substitution effect and a positive coefficient indicates a complementary effect.

An alternative explanation for a positive $\gamma_{3}$, the interaction between political rights and legal institutions, can be motivated by considering that these factors may separately impact the probability of default and the recovery rate in default. That is, if improved political institutions are associated with a lower probability of default, and improved legal institutions imply a greater recovery rate, this would also imply a positive coefficient on $\gamma_{3}$ in equation (4) (as well as negative coefficients on $\gamma_{1}$ and $\gamma_{2}$ ). More concretely, let $\mathrm{V}$ equal the price of a one-period zero coupon bond, $\alpha(\mathrm{L})$ equal the recovery rate as a function of legal rights, $\mathrm{L}, \mathrm{F}$ equal the face value, $p(R)$ equal the probability of bankruptcy as a function of political rights, $R$, and $r_{f}$ equal the riskfree rate. The risk-neutrality and single period assumptions are purely for convenience; the basic intuition does not change if these assumptions are modified. The value of the bond can then be expressed as:

$$
V=\frac{(1-p(R)) F+p(R) \alpha(L) F}{\left(1+r_{f}\right)}
$$

Assuming $p^{\prime}(R)<0$ and $\alpha^{\prime}(L)>0$, that is, the probability of default decreases with political rights and the recovery rate increases with legal institutions, then the first derivatives of value with respect to political and legal rights are positive, and this implies that increases in these variables would cause an increase in $\mathrm{V}$ and therefore a decrease in the yield-to-maturity (or spread). Further,

$$
\frac{d V^{2}}{d R d L}=\frac{p^{\prime}(R) \alpha^{\prime}(L) F}{\left(1+r_{f}\right)}<0
$$


Again, as value and yield are inversely related, this implies that the derivative of the spread with respect to both political rights and legal institutions would have a positive sign. Empirically, this would correspond to a positive $\gamma_{3}$ in equation (4). We empirically examine one of the assumptions behind this small model, specifically whether legal rights but not political rights impact the recovery rate in default, below.

Our third question examines potential channels through which political rights impact credit markets. Roe and Siegel (2007) focus on a socio-political instability index (SPI), as derived by Alesina and Perotti (1996). We consider stability as one aspect of political rights. That is, SPI measures the overall uncertainty about the political and legal environment, and this could impact either existing legal institutions or the basic business environment of the firm.

Besides SPI, we also consider regression analyses with several other variables that are closely correlated with political rights, and that might provide alternative channels through which political rights impact the cost of debt. In particular, we consider freedom of the press, which is positively associated with political rights. For creditors, greater freedom of the press may provide an important check upon misappropriation of funds and thus may help reduce creditor risk. To quote Brandeis (1914), "Publicity is justly commended as a remedy for social and industrial diseases. Sunlight is said to be the best of disinfectants; electric light the most efficient policeman.”

We also consider a measure of corruption, which could impact the risk to debt holders from tunneling (see, for instance, Johnson, La Porta, Lopez-de-Silanes, and Shleifer (2000)); that is, the degree to which creditors would have legal recourse against misappropriation of their capital by managers or shareholders. A fourth factor associated with political rights is expropriation risk, which captures the risk to bondholders from government misappropriation of 
funds (Glaeser, La Porta, Lopez-de-Silanes, and Shleifer (2004)). Thus, we examine whether political institutions matters to credit markets primarily through its relation with one of the above factors; or, conversely, the degree to which each of these factors impacts the cost of debt financing.

\section{Data and Method}

We compile political and legal variables, other country specific characteristics, and bond and firm characteristics from a variety of sources. Table I provides detailed definitions of the variables as well as their sources. In this section, we describe the data collection, our measures of key variables, the selection of control variables, and econometric issues.

\section{A. Sample}

Our analysis is based on a large corporate bond sample which identifies bonds issued by borrowers incorporated in 39 countries between 1980 and 2006. The sample consists of corporate bonds issued in the Eurobond market. We also consider a second sample that includes corporate Yankee bonds to check the consistency of our results across different markets. In order to simplify the presentation, we constrain the primary discussion to the Eurobond sample, and only present the results for Yankee bonds as a robustness check.

We obtain information on corporate bonds from the SDC Platinum Global New Issues

Database. SDC provides comprehensive information about new bond issues in the Eurobond market dating back to 1980 . We focus on new issues data since they provide direct transaction prices which are more accurate than matrix prices taken from secondary data. We require bonds to be denominated in U.S. dollars to mitigate potential problems related to currency conversion and the assessment of different benchmark interest rates. We restrict our sample to fixed-rate 
and floating-rate bonds and notes issued by corporations; agencies, government, or quasigovernment issuers are excluded. Moreover, we exclude any asset-backed securities and convertible bonds. The initial Eurobond sample includes 9,659 bond issues from 2,839 firms incorporated in 77 countries.

\section{B. Measuring Bond Credit Ratings and Bond Yield Spreads}

The dependent variables in our analysis are bond ratings and bond yield spreads. ${ }^{7}$ Our first dependent variable, bond credit rating, measures the perceived risk of the bond. We measure the bonds' credit rating by the S\&P bond rating reported in SDC and convert the letter rating into a number between 21 (AAA) and 1 (C) following the conversion table provided in Appendix A. Whereas ratings from Moody's and Fitch do not always correspond to the S\&P rating, typically they are very close. Moreover, Gande and Parsley (2007) find that the S\&P rating changes (for sovereign debt) typically lead changes by other rating agencies. In unreported results we find that our conclusions hold when we replace the S\&P rating with the average of the S\&P and Moody’s rating.

Our second dependent variable, log bond yield spread at the time of the bond issue, measures the cost of debt (see, for instance, Elton, Gruber, Agrawal, and Mann (2001), Maxwell and Stephens (2003), and Klock, Mansi, and Maxwell (2005)). We distinguish between fixed rate and floating rate bonds in calculating the bond yield spread. The yield spread for fixed rate bonds is defined as the difference between the yield to maturity on a corporate bond and the yield to maturity on its duration equivalent risk-free bond. The yield to maturity at the time of the bond issue on a corporate bond is the discount rate that sets the present value of its future

\footnotetext{
${ }^{7}$ Qian and Strahan (2007) also study other loan characteristics, such as whether the loan is secured and the maturity. We have few theoretical justifications for why political rights should impact these choices, and empirically we find that political rights is not significantly related to these debt characteristics.
} 
payments equal to its offering price. The yield to maturity on a risk-free bond is measured as the yield on the constant maturity Treasury security series obtained from the Federal Reserve Board. If there is no duration equivalent Treasury security available to match the duration of the corporate bond, the yield to maturity on the Treasury security is calculated as the linear interpolation between the two closest maturity matches. ${ }^{8}$

We measure the yield spread for floating rate bonds with a slightly different approach. Floating rate bonds pay interest at a variable rate equal to the rate of a reference bond or index (typically LIBOR) plus the markup or basis point spread. Therefore, we measure the bond yield spread for a floating rate bond as the difference between the reference index and the yield on its corresponding equivalent Treasury security over the first interest period and add the bond's basis point spread. To accommodate a potential mis-measurement between fixed rate bond yield spreads and floating rate bond yield spreads we include a floating bond dummy variable in our regression specification. ${ }^{9}$

\section{Measuring Political Rights and Legal Institutions}

We use an index of political rights as our primary variable to quantify a country’s overall political environment. This measure is obtained from Freedom House (2007) and is constructed for each year from 1980 to 2006 (see also LLSV (1999)). A higher political rights rating indicates a political system that has attributes including free and fair elections, competitive political groupings, an important role and power for the opposition, and a high degree of

\footnotetext{
${ }^{8}$ A variety of more complex interpolation approaches are available, however as we examine only new-issue bonds, $95 \%$ of the Eurobonds have maturities within one year of current treasuries. Thus, the interpolation method should not have a material impact on our results.

${ }^{9}$ Our results remain qualitatively unchanged when we exclude floating rate bonds altogether, although this cuts the Eurobond sample in half (not shown in separate tables). Adding an interaction term between whether the bond is floating and the bond's duration also do not affect our results.
} 
autonomy for entities. This index ranges from one to seven, where a higher rating corresponds to stronger political rights.

We also consider several variables which measure various aspects of a country's political process including the socio-political instability, SPI, (Alesina and Perotti (1996) and Roe and Siegel (2007)); the freedom of the press (Freedom in the World (2007)); the level of corruption (Heritage Foundation and Wall Street Journal (2007)); the risk of expropriation (Glaeser, La Porta, Lopez-de-Silanes, and Shleifer (2004)); and the degree of democracy of a county's political system (Jaggers and Gurr (1996) and LLSV (1999)). We construct the SPI index as in Alesina and Perotti (1996) by considering data from Banks (2005) on politically motivated assassinations, revolutions, and purges of political opposition. The SPI index corresponds to the first principal component for these variables and is calculated for each of the years 1980 to 2006 using an estimation window that spans the 25 years prior to the year in question. Thus this index is time-varying and a higher value indicates a higher degree of socio-political instability. As a robustness test, we also consider the original SPI index constructed by Alesina and Perotti (1996).

We measure the effectiveness of the legal system of a country with an index of aggregate creditor rights following LLSV (1998) and Djankov, McLiesh, and Shleifer (2007). This index is compiled for each year from 1978 to $2003 .{ }^{10}$ Starting from a score of zero, the creditor rights index is incremented by one as each of the following requirements is met: (1) there are restrictions, such as creditor consent or minimum dividends, for a debtor to file for reorganization; (2) secured creditors are able to seize their collateral after the reorganization petition is approved, i.e., there is no automatic stay or asset freeze; (3) secured creditors are paid from the proceeds of liquidating a bankrupt firm before other creditors such as the government or

\footnotetext{
${ }^{10}$ Creditor rights for the years 2004 to 2006 are set equal to the index values observed in 2003.
} 
workers; and (4) management does not retain administration of its property pending the resolution of the reorganization. The creditor rights index ranges from zero to four and a higher score corresponds to stronger creditor rights. In addition to creditor rights, we also compile the following legal institutions variables: an index of property rights that measures the degree to which a country's laws protect private property rights and are enforced by the government (Heritage Foundation and Wall Street Journal (2007); see also La Porta, Lopez-de-Silanes, and Shleifer (2002)); an index of check-based legal formalism (Djankov, La Porta, Lopez-de-Silanes, and Shleifer (2003)); and legal origin variables, which identify the legal origin of the company or commercial law of each country (LLSV (1998 and 1999)).

We merge the bond data with country level political and legal variables. We consider the country of incorporation of the ultimate parent of the borrowing firm as the relevant country under investigation. This process reduces our sample size slightly to 9,337 Eurobonds (from 9,659 bonds).

\section{Control Variables}

We control for bond characteristics, firm characteristics, and country factors. The bondlevel controls include a dummy variable equal to one if the issue is a public bond, a dummy variable equal to one if the issue is a floating rate bond, and dummy variables to capture if the bond is callable or putable. ${ }^{11}$ We also control for the price sensitivity of the bonds to changes in interest rates by including the duration and convexity of the bonds as control variables in our regressions. Duration measures the linear relation between price and yield whereas convexity corrects for the second derivative in the price-yield relation. Both variables measure the

\footnotetext{
${ }^{11}$ Only 14 Eurobonds are putable. The results are unchanged when we exclude them.
} 
systematic risk of the bonds and are calculated following Fabozzi (2000). We also include year and 2-digit SIC industry dummies in all regressions.

We obtain firm-level controls from Worldscope. Worldscope contains balance sheet and income statement data for a large number of publicly listed firms across different countries. We use the SEDOL and ISIN numbers of the borrowers' publicly listed shares, which are reported by both SDC and Worldscope, to match bond-level data with firm-level information. In particular, we extract data to construct firm-level controls that measure firm size (log total assets), return on assets or ROA (net income divided by total assets), leverage (total debt divided by total assets), and growth opportunities as approximated by market-to-book (defined as the market value of equity plus the book value of debt divided by total assets). ${ }^{12}$ The data are obtained at the end of the quarter prior to the bond issue. This procedure ensures that the size, profitability, and leverage variables are unaffected by the proceeds of the debt issue.

The country level controls include log GDP per capita and sovereign rating. We measure the overall country risk with Standard \& Poor's sovereign debt ratings, which are translated into comprehensive credit ratings with values ranging from 0 to 22 (see Gande and Parsley (2007) and Appendix B). We also include a variable for the overall economic development of a country defined as the log of real GDP per capita measured at the year end preceding the bond issue.

In alternative regressions, we also include a dummy variable to capture if the firm has cross-listed equity. The cross-listing data sets are provided by Bank of New York, Citigroup,

\footnotetext{
${ }^{12}$ Alternatively, we measure profitability as earnings before interest and taxes divided by assets and growth opportunities as the market value of equity divided by the book value of equity. Our results are virtually unchanged. Moreover, we add a dummy variable to capture if market-to-book value is missing and replace missing market-tobook values with the sample average.
} 
and JP Morgan. We consider a firm to be cross-listed if it has an ADR program (level I, II, or III) outstanding at the time of the bond issue. ${ }^{13}$

We are able to match about 55\% of the Eurobonds with firm-level data from Worldscope. Our sample size is further reduced because of missing bond rating information, missing bond yield spreads, and incomplete firm-level information. Our final sample corresponds to 2,509 Eurobonds issued by 570 firms from 39 countries.

\section{E. Econometric Issues}

We address the questions posed in Section II with the regression models specified in equations (1) through (4) above. We estimate OLS regressions, calculate robust Huber/White standard errors, and correct for clustering by firm (Petersen (2007)). As in Klock et al. (2005) we also include the residual of bond rating on political and legal institution variables as a control variable in equations (2) and (4). This allows us to examine the marginal impact of a difference in our institutional variables on the cost of debt regardless of whether that change is captured by the rating agencies. In alternative specifications, we also consider random country effects as in LLSV (2002) and Doidge, Karolyi, and Stulz (2004); however, this approach understates the standard errors relative to the more conservative firm-clustering robust errors we report. Fixed effects regressions, where the coefficients are determined by changes in the variables over time for a given firm, also produce consistent results.

Lastly, when considering a number of political variables in the same regression, we encounter some problems with multicollinearity. We therefore consider regressions where we

\footnotetext{
${ }^{13}$ Firms that have a GDR program in place are not regarded as cross-listed; only 20 firms in the Eurobond sample have GDR programs contemporaneous to the debt issue. Including dummy variables for GDRs does not otherwise change our results. Additionally, Canadian firms that cross-list in the U.S. do not use ADR programs but list their stocks directly on U.S. exchanges. Our results do not change if we include these Canadian direct listings with the ADRs.
} 
orthogonalize the political variables using the process described in Golub and Van Loan (1996). However, this orthogonalization makes the economic impact of each variable more difficult to interpret. Therefore, we emphasize the regular OLS regressions in our discussion, and present the orthogonalized results as a robustness check.

\section{Empirical Results}

\section{A. Summary Statistics}

Table II presents the distribution by country and decade of the observations. We have all data available for 2,509 Eurobonds. The countries with the largest representation are the U.S. (799 issues), Japan (231 issues), Australia (214 issues), Germany (213 issues), and the U.K. (180 issues). Table III lists means for selected variables by country for the Eurobond sample.

Table IV present correlation coefficients for our variables of interest. As expected, political rights are positively correlated with freedom of the press (0.66), negatively correlated with socio-political instability, SPI, (-0.21), negatively correlated with corruption (-0.39), and negatively correlated with expropriation risk (-0.55). Political rights also have a high correlation with the democracy score variable (0.65), suggesting that these two variables measure the same underlying factor. Political rights have a relatively small negative correlation with creditor rights $(-0.14)$. This relatively low correlation between political and creditor rights suggests that these variables capture separate effects.

The correlation between the log yield spread (credit rating) and political rights is negative (positive) and significant. Similar results hold for the correlation between the log yield spread and creditor rights. The correlation between sovereign ratings and bond ratings is positive and 
significant at 0.42 . Additionally, $3 \%$ of individual corporate bonds have ratings higher than the corresponding sovereign ratings. ${ }^{14}$

Table V provides descriptive statistics for our Eurobond sample. Average bond ratings are between $\mathrm{A}$ and $\mathrm{A}+$. Median spreads are approximately 55 basis points higher than the corresponding treasuries; however the spread is highly skewed with a mean almost double the median. Political rights are on average high at 6.84 out of 7 , whereas average creditor rights are 1.92 out of 4 .

\section{B. Institutions and Credit Ratings}

Table VI presents our estimates from regressing S\&P bond ratings on political and legal variables, country variables, firm characteristics, and issue characteristics for the Eurobond market. Column (1) presents our basic specification with political rights, creditor rights, log GDP per capita, and firm characteristics. Column (2) adds security characteristics to the analysis. The security characteristics may be endogenously determined; however, in practice we find that the estimates on our coefficients of interest are negligibly impacted by whether these variables are included (and this holds true for all our specifications). Column (3) adds sovereign rating as an additional explanatory variable. Column (4) adds the interaction between political and creditor rights to the basic regression. To capture marginal effects we consider the portion of the interaction term which is orthogonal to political rights and creditor rights; that is, we first regress this interaction against political rights and creditor rights, and consider the residual from that regression as our measure for the interaction term. Column (5) adds the SPI index, freedom of the press, corruption, and expropriation risk as additional explanatory variables to the

\footnotetext{
${ }^{14}$ Borensztein, Cowan, and Valenzuela (2007) provide an extensive study on the relation between sovereign and corporate ratings in emerging markets.
} 
specification in column (2), and column (6) drops political rights. In alternative specifications, we exclude the issue-specific characteristics; however, this does not impact our results.

Consistent with our primary hypothesis, higher political rights are associated with higher bond ratings, and this result holds for all of our specifications. Consistent with Qian and Strahan (2007), higher creditor rights are associated with improved credit ratings. The economic impact of political rights and creditor rights is significant; given the results in column (2), a one standard deviation change in political rights (equal to 0.747 , see Table V) implies a change of $0.42(0.747$ times 0.556 ) in rating, whereas a one standard deviation change in creditor rights (equal to 1.138) implies a 0.66 (1.138 times 0.576) change in rating.

While one might expect that sovereign rating would capture much of the political and legal environment embodied in the security rating, this is not the case. Higher sovereign credit ratings are associated with significantly higher corporate bond ratings. However, this does not eliminate the impact of political and legal country variables. The coefficients on creditor rights and political rights decline slightly in column (3) with sovereign ratings relative to the estimated coefficients in column (2) without sovereign rating, though neither decline is significant. The coefficient on political rights only declines by $26 \%$ and the coefficient on creditor rights declines by $12 \%$.

Column (4) provides information about the interaction between political and creditor rights. The estimated coefficient on the interaction is negative but not significant for ratings. Column (5) includes the four variables which capture different possible channels through which political rights may manifest: SPI, freedom of the press, corruption, and expropriation risk. However, with the exception of corruption, these variables are not significant in the bond rating regressions, and the coefficient on political rights is only slightly reduced by adding these 
variables. Thus, at least as far as bond ratings are concerned, these variables do not explain the primary impact of political rights. Column (6) considers the same regression but without political rights, and though the freedom of the press coefficient now increases, it is still not significantly different from zero. We examine the issues raised by these regressions in more detail by considering regressions on the cost of debt below.

The estimated coefficients on our other control variables are on the whole consistent with our expectations. Larger firms, as measured by log total assets, typically have higher ratings, and higher ROA is associated with a higher rating. The estimated coefficient on leverage is negative in several specifications, but surprisingly it is not significant. This finding is mostly driven by the correlations between ROA, the public bond dummy, and leverage. If we drop the ROA and public bond variables, leverage becomes negative and significant for all specifications (not shown in separate tables). Public bond issues are also associated with higher credit ratings. Log GDP per capita is also positive and significant in regressions that do not include sovereign ratings or corruption.

\section{Institutions and the Cost of Debt Capital}

Table VII presents estimates from regressions of the log spread over treasury bonds on our political and legal variables, country characteristics, firm characteristics, and security characteristics for the Eurobond market. Similar to Table VI, column (1) presents the regression estimates without security characteristics. Column (2) adds the potentially endogenous security characteristics, which again do not impact our coefficients of interest. Column (3) adds sovereign ratings, column (4) includes the interaction between political and creditor rights (as above, this is the portion of the interaction orthogonal to political and creditor rights), column (5) adds SPI, freedom of the press, corruption, and expropriation risk to the basic specification, and 
column (6) drops political rights. As with the ratings regressions, we also examine regressions without issue characteristics as these may be simultaneously determined; however, these specifications provide results similar to those in Table VII for our variables of interest and are therefore not reported.

Overall, we find strong evidence supporting the impact of political rights on the cost of debt; the coefficients on political rights are negative and significant in all specifications. A one standard deviation change in political rights equals 0.747 in the Eurobond market, and thus a one standard deviation increase in political rights would imply on average an 18.6\% (0.747 times $-0.249)$ decrease in spreads in column (2).

As in Qian and Strahan (2007), we find that greater creditor rights are associated with lower bond spreads, and the marginal impact in our study is similar to theirs. The coefficients in our study range from -0.093 to -0.113 versus -0.100 to -0145 for the full sample in Qian and Strahan. The economic impact on bond spreads of a one standard deviation change in creditor rights is slightly smaller than that from a one standard deviation change in political rights. From column (2), a one standard deviation increase in creditor rights of 1.138 would imply a $12.9 \%$ (1.138 times -0.113) decline in spreads.

As expected, we find that higher sovereign ratings are associated with lower yield spreads. An increase of 1.0 in sovereign rating implies a spread decrease of $6.1 \%$ in the Eurobond market given the estimate in column (3). Similar to the analysis of bond ratings, adding sovereign rating fails to capture most of the impact of political or creditor rights.

The specification in column (4) of Table VII considers the interaction between political and creditor rights. Unlike in the ratings regressions, this interaction is significant and positive for yield spreads. This positive coefficient suggests some substitution between political and 
creditor rights, or a smaller impact of creditor rights on bond spread for firms from countries with greater political rights (and vice versa). This finding is consistent with Djankov, Glaeser, La Porta, Lopez-de-Silanes, and Shleifer (2003) in which property rights (i.e., control for disorder) substitute for political institutions (i.e. control for dictatorship). This finding is also consistent with a model in which political rights impact the probability of default whereas creditor rights impact the recovery rate in default. Note that while the interaction effect is not significant in regressions on bond rating reported in Table VI, it is strongly significant in the regressions on cost of debt. The impact of political rights is also more robust (economically and statistically) in the cost of debt regressions than in the ratings regressions, suggesting that credit markets are more sensitive than rating agencies to these issues, or that rating agencies do not take into account political rights and their interaction with legal institutions as much as investors.

In order to test whether the interaction term is significant because of the separate impacts of political and legal rights on the probability of default and the recovery in default, respectively (as equation (6) suggests), we conduct the following test. We consider the sample of all firms which issued both junior and senior debt at approximately the same time. As these bond issues are from the same firms, the difference in spreads between them should be a function of the recovery rate rather than the probability of bankruptcy. Under our simple assumptions, this spread should therefore be explained by legal institutions rather than political rights (after controlling for duration and other bond-specific factors). This matching produces a sample of 47 junior and senior bond pairs issued within a one year window of each other, or 12 bond pairs issued within 90 days of each other. In unreported regressions, we find that the spread difference between junior and senior debt is not significantly explained by either political or legal rights. This suggests that the strict model provided above, where political rights impact default 
probabilities while legal rights impact recovery rates, may be too limited. Alternatively, the power of our tests may be too low given the limited sample size. ${ }^{15}$ Overall, the significant coefficients on the interaction between political and legal variables and the lack of significance on the difference between junior and senior debt spreads are more consistent with the substitution between political and legal institutions suggested by Djankov et al. (2003) than with the simple model presented in equations (5) and (6) above.

We find limited evidence that political rights can be subsumed by our other institutional variables in column (5) of Table VII. Greater SPI is associated with higher spreads, although this effect is only significant at the $10 \%$ level. Also, corruption and expropriation risk are significant in column (5); however, political rights continues to have a significant impact on spreads. ${ }^{16}$ In column (6), when political rights are excluded, freedom of the press becomes significant and negative, while corruption and expropriation risk appear to have similar effects to those estimated in column (5). SPI is not significant in column (6).

Overall, the results in columns (5) and (6) have several implications. First, political rights continues to be a good measure of the importance of a country's political institutions even if other measures, such as instability, freedom of the press, corruption, and expropriation risk, are included. Second, political rights impact the cost of debt partly through the same channel as freedom of the press; if both are included in a regression, political rights is significant, but freedom of the press becomes highly significant (statistically and economically) if political rights is not included. ${ }^{17}$ Third, corruption and expropriation risk are both associated with higher spreads, and these effects persist whether or not political rights are included. Fourth, SPI is a

\footnotetext{
${ }^{15}$ We also calculate the correlation between average recovery rates and creditor rights for the nine countries for which Moody's (2003) provides data, and we find no evidence of a positive relation.

${ }^{16}$ Expropriation risk has a large negative correlation with sovereign rating (-0.88 for the Eurobond sample), and these two variables appear to capture much of the same impacts.

${ }^{17}$ Measures of accounting standards (LLSV (1998)) do not capture the same effect as freedom of the press.
} 
relatively poor measure of the impact of political rights on the cost of debt. This suggests that the methodology of Alesina and Perotti (1996) does not necessarily provide us with an index which effectively captures the future political risk in a country, even if, as we do, the SPI is reestimated for the 25 years prior to the date in question.

The coefficients on the other control variables in Table VII are largely consistent with our expectations. Some of the marginal effects on these coefficients, such as profitability or leverage, may also be captured by our rating variable. Specifically, we find that more profitable firms have lower spreads and firms with greater leverage have higher spreads, although this last effect is not significant. ${ }^{18}$ Public bonds have lower spreads, and floaters have higher spreads. Callable bonds have higher spreads, whereas putable bonds have lower spreads. Spreads also increase with duration, and the residual of rating on institutional variables is an important component in explaining the spread.

\section{Robustness Tests}

We consider a number of robustness checks of our results. Several papers (see for instance, LLSV (1998 and 2002), Beck, Demirguc-Kunt, and Levine (2003), and Beck and Levine (2004)) consider legal origin as a primary determinant of legal and institutional factors and argue that these variables are of primary importance in explaining institutional factors impacts on markets. Therefore, we add dummy variables in the first three columns of Table VIII for French, German, Scandinavian, or Socialist legal origin to our specification (English legal origin is the excluded variable). We find that German legal origin, and to a lesser extent Scandinavian legal origin, is associated with a lower cost of debt in most specifications, while

\footnotetext{
${ }^{18}$ As in the ratings regressions, this finding is mostly driven by the correlations between ROA, public bond issue, and leverage. If we drop the ROA and public bond variables, the coefficient of leverage becomes positive and significant. Moreover, part of the effect of leverage is captured by the bond rating variable.
} 
Socialist legal origin is associated with a higher cost of debt. However, including these variables does not change the significance or magnitude of the effect of political rights on the cost of debt. Political rights appear to have a separate effect from legal origin in terms of how credit markets function. Including these legal origin variables does however decrease the impact of creditor rights on debt by $46 \%$ to $33 \%$.

In columns (4) and (5) of Table VIII, we replace the political rights variable with the democracy score variable as in Jaggers and Gurr (1996) or LLSV (1999). Unlike political rights, the democracy score is not time-varying, but the two are highly correlated (correlation coefficient equal to 0.65). Our results are similar; more democracy implies lower yields in the same manner as political rights. In unreported regressions, we also find that higher democracy scores are associated with higher bond ratings.

We consider the original SPI index of Alesina and Perotti (1996) as an alternative measure of instability in columns (6) and (7) of Table VIII. Using data from 1960 to 1985, we find that this non-time varying measure actually captures the risk of spreads more effectively than our more recent time-varying SPI. However, this stronger finding may be an artifact of the data as we would expect a more recent time-varying measure to work more effectively. ${ }^{19}$ Alternatively, political instability may partly impact financial markets through lagged long-term effects (Rajan and Zingales (2003) and Roe (2006)). Thus, the more distant political instability measured by Alesina and Perotti’s SPI may actually be more important to how credit markets are set up than the more recent instability we measure.

A number of papers have studied how cross-listing can increase firm value. For instance, some authors argue that firms may be able to effectively bond themselves to higher creditor

\footnotetext{
${ }^{19}$ Our SPI estimate also includes more countries than that estimated by Alesina and Perotti (1996). We also estimate a non-time varying version of SPI over the years in our sample, and that variable is actually more significantly correlated with the cost of debt than the time-varying version reported in Table VII.
} 
protection laws in the U.S. (Fuerst (1998), Stulz (1999), and Coffee (1999)). Subrahmanyam and Titman (1999) argue that listed (or cross-listed) shares convey extra information to the market which reduces uncertainty and can lower the cost of capital. Alternatively, Siegel (2005) suggests that cross-listing could provide an increase in reputation for foreign firms. A related theory is Merton's (1987) investor recognition hypothesis, in which more visible firms have higher prices. We present regressions with a dummy variable for whether the firm is cross-listed in the U.S. in columns (8) through (10) of Table VIII. ${ }^{20}$ We find that firms which cross-list see no significant change in spreads for the Eurobond sample.

As a further robustness test, we repeat all our regressions using a sample of 1,076 corporate Yankee bonds by 373 firms from 36 countries (detailed descriptive statistics are available upon request). The data is obtained from the same sources as for the Eurobond sample.

Political rights, freedom of the press, and corruption measures are similar across the two samples. Expropriation risk is higher in the Yankee bond sample than in the Eurobond sample (0.44 versus 0.33 ), and creditor rights are slightly lower for Eurobonds than for Yankee bonds (1.92 versus 2.16). Eurobond issuers are on average larger than issuers of Yankee bonds ( $\$ 208$ billion versus $\$ 155$ billion). Consistent with Miller and Puthenpurackal (2005) yield spreads are significantly lower in Eurobond markets than for Yankee bond market, and these lower Eurobond spreads persist after controlling for ratings and other factors. Eurobonds also tend to have shorter maturities and durations than Yankee bonds (duration of 2.55 years versus 6.70 years), are less likely to be callable (18\% versus $40 \%$ ), are more likely to be floaters ( $46 \%$ versus $13 \%$ ), and are more likely to be public issues (85\% versus $68 \%$ ).

The regression results for the Yankee bonds in Table IX are remarkably consistent with the findings described above. Political rights and creditor rights are both important determinants

\footnotetext{
${ }^{20}$ The smaller sample size in these regressions is due to the exclusion of U.S. firms from the cross-listing sample.
} 
of ratings and spreads, and the interaction between these two variables is again positive and significant in the spread regressions, suggesting a substitution effect. However, the impact of SPI using this sample is now counter to our expectations. More instability implies higher ratings and lower yields. We believe this perverse result is caused by multicollinearity, and address this issue explicitly below. Otherwise, our other variables associated with political rights have similar impacts in the Yankee bond market as in the Eurobond market, with greater freedom of the press associated with lower yields and greater expropriation risk associated with higher yields.

An interesting difference between the Eurobond and Yankee bond samples is that crosslisting is associated with a significantly lower yield in the U.S. bond samples as reflected in the estimated coefficients in columns (7) and (8) of Table IX. If the binding effect documented by Doidge (2004) or Doidge, Karolyi, and Stulz (2004) is responsible for the lower spreads enjoyed by Yankee bond issues, we would expect that the impact of cross-listing would be higher for bonds from countries with weaker creditor rights. In unreported regressions, we therefore consider interactions between cross-listing and creditor rights, political risk, and our other legal and institutional variables. These interactions are not significant for both the Eurobond and U.S. bond market samples, and this result is not consistent with binding to U.S. laws providing greater creditor, as well as minority shareholder protection. ${ }^{21}$ Instead, the lower spreads for Yankee bonds of cross-listed firms are consistent with Merton's investor recognition hypothesis, whereby foreign firms with cross-listed equity gain greater U.S. visibility and thus benefit from lower U.S. yield spreads. All these results are unchanged if we only consider Level II and III ADRs. In unreported regressions, we also consider a self-selection model for whether a firm

\footnotetext{
${ }^{21}$ We emphasize that these results do not contradict a binding hypothesis for minority shareholders which would impact stock valuation, only that these binding effects do not appear to spill over to bond markets.
} 
cross-lists in the U.S. as in Doidge, Karolyi, and Stulz (2004); however, the self-selection correction has little impact on our primary results.

In Table $\mathrm{X}$ we consider whether our results are robust to a firm fixed effects specification. The Eurobond data set includes 280 firms with multiple bond issues, while the Yankee bond market data includes 178 firms with multiple issues. As in Table VII, the estimated coefficients from regressing the log of the bond spreads on political rights are significant and negative when other political variables are not included. In unreported results, we also find the corresponding effects of greater political rights associated with higher ratings. Some of the other effects we document above, such as higher spreads with greater corruption in the Eurobond market and lower spreads with greater freedom of the press in the Yankee bond market, also hold in the fixed effects regressions. However, not surprisingly, some of the effects documented in the prior regressions are not captured by the limited changes in variables for this smaller sample.

In order to more effectively disentangle the marginal impacts of our political variables, we orthogonalize the political variables as in Golub and Van Loan (1996) and report our results in Table XI. That is, we regress SPI on political rights and include the residual as the marginal measure of SPI. We then regress freedom of the press on political rights and SPI, and use the residual as the marginal measure of freedom of the press, and so on. This procedure largely produces the expected signs on all the variables of interest, that is, SPI is positively associated with spreads (not significant in the Yankee bond sample), freedom of the press is negatively associated with spreads, corruption is positively associated with spreads, and expropriation risk is positively associated with spreads. The reverse effect is found for bond ratings. Thus, the 
results in Table XI demonstrate that the marginal impacts of these variables are consistent with our expectations.

In unreported regressions, we also consider alternatives for creditor rights including property rights as in La Porta, Lopez-de-Silanes, and Shleifer (2002) or legal formalism as in Djankov, La Porta, Lopez-de-Silanes, and Shleifer (2003). These variables appear to capture much of the same impact as creditor rights and produce similar results. We also pool the Eurobond and Yankee bond samples and add a dummy variable for Eurobond issues. As expected, our primary results on political and legal variables hold strongly for the merged sample (as they do for the individual samples). We also find that the estimated coefficient on whether an issue is in the Eurobond market is positive and significant for the rating regressions and negative and significant for the spread regressions. These regressions confirm the lower spreads for Eurobond issues documented by Miller and Puthenpurackal (2005), and the economic impact we estimate is similar to theirs.

In unreported regressions, we exclude financial firms and U.S. issuer Eurobonds and find similar results to those in our primary specifications. We also exclude firm-level variables altogether, which increases our sample size considerably, and find consistent results. We also consider a principal component factor analysis which uses all the legal institutional variables in the existing literature. We find that the primary factors are closely correlated with creditor rights and political rights. As the overall impact on the cost of debt capital from using these factors is similar to what we report in our primary specifications, we do not present this analysis.

\section{Conclusions}

This paper examines the impact of country-level political rights on credit markets while controlling for legal institutions. Higher political rights are associated with significantly higher 
ratings and lower spreads for corporate bonds issued in both the Eurobond and the Yankee bond markets. A one standard deviation change in political rights is associated with an $18.6 \%$ decline in yield spreads on average. We find that the interaction term between political rights and creditor rights is positively associated with yield spreads, thus political rights and creditor rights partially act as substitutes.

We also consider the channels by which political rights impact bond markets. Sociopolitical instability in the 25 years prior to the bond issue has limited impact on the cost of debt, suggesting that political rights are more important as a forward looking measure of bondholder risk. On the other hand, freedom of the press appears to capture much of the effects of political rights, suggesting that part of the advantages of political freedom to credit markets may be due to greater information availability. Corruption and expropriation risk are also priced in bond yields. However, the effects of these variables appear to be more independent of political rights.

Whereas prior research has focused on the long-run effect of political instability in damaging institutions and markets (Rajan and Zingales (2003) and Roe (2006)), we find that concurrent measures of political rights significantly impact the cost of debt. Besides the benefits of lower corruption and expropriation risk, a more open democratic environment provides significant forward-looking benefits by further reducing the cost of debt capital. This reduction may be partly due to expected changes in future instability or differences in information quality, and these effects are not captured by differences in legal rights. 


\section{References}

Alesina, Alberto, and Roberto Perotti, 1996. Income distribution, political instability, and investment, European Economic Review 40, 1203-1228.

Allen, Franklin, Jun Qian, and Meijun Qian, 2005. Law, finance, and economic growth in China, Journal of Financial Economics 77, 57-116.

Banks, Arthur S., 2005. Cross-national time-series data archive (Databanks International, Binghamton, NY.).

Beck, Thorsten, and Ross Levine, 2004. Legal institutions and financial development, NBER Working Paper No. W10417.

Beck, Thorsten, Asli Demirguc-Kunt, and Ross Levine, 2003. Law, endowments and finance, Journal of Financial Economics 70, 137-181.

Borensztein, Eduardo, Kevin Cowan, and Patricio Valenzuela, 2007. Sovereign ceilings “lite”? The impact of sovereign ratings on corporate ratings in emerging market economies, IMF Working Paper 07/75.

Brandeis, Louis D., 1914, Other people's money and how the bankers use it (Frederick A. Stokes Co., NY., http://library.louisville.edu/law/brandeis/opm-ch5.html).

Cantor, Richard, and Frank Packer, 1996a. Determinants and impact of sovereign credit ratings, Federal Reserve Bank of New York Economic Policy Review, 1-15.

Cantor, Richard, and Frank Packer, 1996b. Sovereign risk assessment and agency credit ratings, European Financial Management 2, 247-256.

Click, Reid, 2005. Financial and political risks in US direct foreign investment, Journal of International Business Studies 36, 559-575.

Coffee, John C. Jr., 1999. The future as history: the prospects for global convergence in corporate governance and its implications, Northwestern University Law Review 93, 641708.

Coffee, John C. Jr., 2001. The rise of dispersed ownership: the roles of law and the state in the separation of ownership and control, Yale Law Journal 111, 1-82.

Demirguc-Kunt, Asli, and Vojislav Maksimovic, 1998. Law, finance, and firm growth, Journal of Finance 52, 2107-2139.

Demirguc-Kunt, Asli, and Vojislav Maksimovic, 1999. Institutions, financial markets, and firm debt maturity, Journal of Financial Economics 54, 295-336. 
Djankov, Simeon, Edward Glaeser, Rafael La Porta, Florencio Lopez-de-Silanes, and Andrei Shleifer, 2003. The new comparative economics, Journal of Comparative Economics 31, 595-619.

Djankov, Simeon, Rafael La Porta, Florencio Lopez-de-Silanes, and Andrei Shleifer, 2003. Courts, The Quarterly Journal of Economics 118, 453-517.

Djankov, Simeon, Caralee McLiesh, and Andrei Shleifer, 2007. Private credit in 129 countries, Journal of Financial Economics 84, 299-329.

Doidge, Craig, 2004. U.S. cross-listings and the private benefits of control: evidence from dualclass firms, Journal of Financial Economics 72, 519-553.

Doidge, Craig, G. Andrew Karolyi, and René M. Stulz, 2004. Why are foreign firms listed in the U.S. worth more? Journal of Financial Economics 71, 205-238.

Easterly, William, and Ross Levine, 1997. Africa's growth tragedy: polices and ethnic divisions, Quarterly Journal of Economics 112, 1203-1250.

Elton, Edwin J., Martin J. Gruber, Deepak Agrawal, and Christopher Mann, 2001. Explaining the rate spread on corporate bonds, Journal of Finance 56, 247-277.

Fabozzi, Frank J., 2000. Bond markets, analysis and strategies (Prentice Hall, Upper Saddle River, NJ.).

Freedom House, 2007. Annual freedom in the world survey: political rights and civil liberties rating 1972-2006, http://www.freedomhouse.org.

Frum, David, 2007. Where emerging markets are safe, NPR Marketplace Report, September 5, 2007.

Fuerst, Oren, 1998. A theoretical analysis of the investor protection regulations argument for global listing of stocks, Yale University Working Paper.

Gande, Amar, and David Parsley, 2007. Sovereign credit ratings, transparency and international portfolio flows, SMU Working Paper.

Glaeser, Edward L., and Andrei Shleifer, 2002. Legal origins, Quarterly Journal of Economics 117, 1193-1229.

Glaeser, Edward L., Rafael La Porta, Florencio Lopez-de-Silanes, and Andrei Shleifer, 2004. Do institutions cause growth? Journal of Economic Growth 9, 271-303.

Glaeser, Edward L, and Andrei Shleifer, 2003. The rise of the regulatory state. Journal of Economic Literature 41, 401-425.

Golub, Gene H., and Charles F. Van Loan, 1996. Matrix computations (Johns Hopkins University Press, Baltimore, MD.). 
Haber, Stephen, 2005. Political institutions and financial development: evidence from the economic histories of Mexico and the United States, Stanford Center for International Development Working Paper No. 268.

Heritage Foundation and Wall Street Journal, 2007. Index of economic freedom 1995-2006, http://www.heritage.org.

Jaggers, Keith, and Ted R. Gurr, 1996. Polity III: regime change and political authority 18001994, Ann Arbor, Inter-University Consortium for Political and Social Research.

Johnson, Simon, Rafael La Porta, Florencio Lopez-de-Silanes, and Andrei Shleifer, 2000. Tunneling, American Economic Review 90, 22-27.

Kaminsky, Graciela, and Sergio L. Schmukler, 2002. Emerging market instability: do sovereign ratings affect country risk and stock returns? World Bank Economic Review 16, 171-195.

Klock, Mark S., Sattar A. Mansi, and William F. Maxwell, 2005. Does corporate governance matter to bondholders? Journal of Financial and Quantitative Analysis 40, 693-720.

La Porta, Rafael, Florencio Lopez-de-Silanes, and Andrei Shleifer, 2002. Government ownership of banks, Journal of Finance 57, 265-301.

La Porta, Rafael, Florencio Lopez-de-Silanes, Andrei Shleifer, and Robert W. Vishny, 1997. Legal determinants of external finance, Journal of Finance 52, 1131-1150.

La Porta, Rafael, Florencio Lopez-de-Silanes, Andrei Shleifer, and Robert W. Vishny, 1998. Law and finance, Journal of Political Economy 106, 1113-1155.

La Porta, Rafael, Florencio Lopez-de-Silanes, Andrei Shleifer, and Robert W. Vishny, 1999. The quality of government, Journal of Law, Economics and Organization 15, 222-279.

La Porta, Rafael, Florencio Lopez-de-Silanes, Andrei Shleifer, and Robert W. Vishny, 2000. Investor protection and corporate governance, Journal of Financial Economics 8, 3-27.

La Porta, Rafael, Florencio Lopez-de-Silanes, Andrei Shleifer, and Robert W. Vishny, 2002. Investor protection and corporate valuation, Journal of Finance 57, 1147-1170.

Levine, Ross, 1999. Law, finance and economic growth, Journal of Financial Intermediation 8, 8-35.

Maxwell, William F., Clifford P. Stephens, 2003. The wealth effects of repurchases on bondholders, Journal of Finance 58, 895-920.

Merton, Robert C., 1987. Presidential address: a simple model of capital market equilibrium with incomplete information, Journal of Finance 42, 483-510. 
Milhaupt, Curits J., and Katharina Pistor, 2007. Law and capitalism: what corporate crises reveal about legal systems and economic development around the world (University of Chicago Press, Chicago, IL.).

Miller, Darius P., and John Puthenpurackal, 2005. Security fungibility and the cost of capital: evidence from global bonds, Journal of Financial and Quantitative Analysis 40, 850-872.

Moody's Special Comment, 2003. Recovery rates on defaulted corporate bonds and preferred stocks, 1982-2003.

Petersen, Mitchell A., 2007. Estimating standard errors in finance panel data sets: comparing approaches, Review of Financial Studies, forthcoming.

Qian, Jun, and Philip E. Strahan, 2007. How laws and institutions shape financial contracts: The case of bank loans, Journal of Finance 62, 2553-2554.

Rajan, Raghuram G., and Luigi Zingales, 2003. The great reversals: The politics of financial development in the twentieth century, Journal of Financial Economics 69, 5-50.

Roe, Mark J., 2006. Legal origins and modern stock markets, Harvard Law Review, forthcoming.

Roe, Mark J., and Jordan I. Siegel, 2007. Political instability and financial development, Harvard University Working Paper.

Siegel, Jordan I., 2005. Can foreign firms bond themselves effectively by renting U.S. laws? Journal of Financial Economics 75, 319-359.

Stulz, René M., 1999. Globalization, corporate finance, and the cost of capital, Journal of Applied Corporate Finance 12, 8-25.

Subrahmanyam, Avanidhar, and Sheridan Titman, 1999. The going-public decision and the development of financial markets, Journal of Finance 54, 1045-1082. 


\section{Table I \\ Variable definitions}

\begin{tabular}{ll}
\hline Variable & Description \\
\hline
\end{tabular}

\section{A. Political variables}

Political rights

Socio-political instability [referred to as SPI]

Socio-political instability by Alesina and Perotti (1996) [referred to as SPI AP]

Freedom of the press

Corruption

Expropriation risk

Democracy
An index of political rights. Higher ratings indicate countries that come closer "to the ideals" suggested by questions relating to: there are free and fair elections; those elected rule; there are competitive parties or other competitive political groupings; the opposition has an important role and power; and the entities have self-determination or an extremely high degree of autonomy. The index is time-varying and ranges from 1 (weak political rights) to 7 (strong political rights) and is constructed for every year from 1980 to 2006. Sources: Freedom House (2007), and La Porta, Lopez-de-Silanes, Shleifer, and Vishny (1999).

An index that measures the socio-political instability of a country. The index is constructed by using principal component analysis to the following variables (see also Alesina and Perotti (1996)): Assassinations (number of politically motivated murders or attempted murders of high government officials or politicians); revolutions (any illegal or forced change in the top governmental elite, any attempt at such a change, or any successful or unsuccessful armed rebellion whose aim is independence from the central government); and purges (any systematic elimination by jailing or execution of political opposition within the ranks of the regime or the opposition). The index corresponds to the first principal component and is calculated for each of the years 1980 to 2006 using an estimation window that spans over the 25 years prior to the year in question. The index is time-varying and higher values indicate a higher degree of socio-political instability. Sources: The data are from Banks (2005).

An index that measures the socio-political instability of a country. The index is constructed by applying the method of principal component to the following variables: number of politically motivated assassinations; number of people killed in conjunction with phenomena of domestic violence; number of successful coups; number of unsuccessful coups; and democracy indicator. The index is created using data for the period of 1960 to 1985 and is non-time-varying. Higher values indicate a higher degree of socio-political instability. Source: Alesina and Perotti (1996)

An index of freedom of the press. Higher scores mean higher freedom of the print and broadcast media in a country. The index is time-varying and ranges from 0 (not free) to 10 (free) and is constructed for every year from 1980 to 2006. Sources: Freedom House (2007).

An index of freedom from corruption. It is based on quantitative data that assess the perception of corruption in the business environment, including levels of governmental legal, judicial, and administrative corruption. The index is time-varying and ranges from 1 (very little corruption) to 10 (corrupt government) and is constructed for every year from 1995 to 2006. Index values for years prior to 1995 are set equal to those observed in 1995. Sources: Heritage Foundation and Wall Street Journal (2007).

Risk of "outright confiscation and forced nationalization" of property. This variable ranges from 0 (low probability of expropriation) to 10 (high probability of expropriation) and is calculated as the average from 1982 through 1997. Sources: International Country Risk Guides, and Glaeser, La Porta, Lopez-de-Silanes, and Shleifer (2004)

Average of democracy score for the period 1970 to 1994. The score ranges from 0 to10, with lower values indicating a less democratic environment. Source: Jaggers and Gurr (1996), and La Porta, Lopez-de-Silanes, Shleifer, and Vishny (1999). 


\section{B. Legal variables}

Creditor rights

Property rights

Legal formalism

Legal origin

Real GDP per capita

Log GDP per capita

Sovereign rating

Yield spread
An index aggregating creditor rights. A score of one is assigned when each of the following rights of secured lenders are defined in laws and regulations: (1) there are restrictions, such as creditor consent or minimum dividends, for a debtor to file for reorganization; (2) secured creditors are able to seize their collateral after the reorganization petition is approved, i.e., there is no automatic stay or asset freeze; (3) secured creditors are paid first out of the proceeds of liquidating a bankrupt firm, as opposed to other creditors such as government or workers; and (4) management does not retain administration of its property pending the resolution of the reorganization. The index ranges from 0 (weak creditor rights) to 4 (strong creditor rights) and is constructed for every year from 1978 to 2003 . The index is time-varying and index values for the years 2004 to 2006 are set equal to the index values of the year 2003. Sources: Bankruptcy and reorganization laws, Djankov, McLiesh, and Shleifer (2007), and La Porta, Lopez-de-Silanes, Shleifer, and Vishny (1998).

An index of property rights in each country. It scores the degree to which a country's laws protect private property rights and the degree to which its government enforces those laws. It also assesses the likelihood that private property will be expropriated and analyzes the independence of the judiciary, the existence of corruption within the judiciary, and the ability of individuals and businesses to enforce contracts. The more protection private property receives, the higher the score. The index is time-varying and ranges from 1 (weak property rights) to 10 (strong property rights) and is constructed for every year from 1995 to 2006. Index values for years prior to 1995 are set equal to those observed in 1995. Sources: Heritage Foundation and Wall Street Journal (2007); see also La Porta, Lopez-de-Silanes, and Shleifer (2002).

An index of check-based legal formalism. The index measures substantive and procedural statutory intervention in judicial cases at lower-level civil trial courts, and is formed by adding up the following indices: (1) professionals versus laymen; (2) written versus oral elements; (3) legal justification; (4) statutory regulation of evidence; (5) control of superior review; (6) engagement formalities; and (7) independent procedural actions. The index ranges from 0 (high control or intervention in the judicial process) to 7 (low control or intervention in the judicial process). Source: Djankov, La Porta, Lopez-de-Silanes, and Shleifer (2003).

Identifies the legal origin of the company law or commercial code of each country (English, French, Socialist, German, and Scandinavian). Source: La Porta, Lopez-deSilanes, Shleifer, and Vishny (1998 and 1999).

\section{Other country specific characteristics}

Real GDP per capita in U.S. dollars (basis: year 2000). Source: World Bank.

Logarithm of real GDP per capita.

We code Standard \& Poors sovereign credit ratings into Comprehensive Credit Rating (CCR) as described in Appendix B following Gande and Parsley (2007). Source: Standard \& Poors.

\section{Bond specific variables}

The yield spread for fixed rate bonds is defined as the difference between the yield to maturity on a corporate bond and the yield to maturity on its duration equivalent riskfree bond. The yield to maturity at the time of the bond issue on a corporate bond is the discount rate that sets the present value of its future payments equal to its offering price. The yield to maturity on a risk-free bond is measured as the yield on the constant maturity Treasury security series obtained from the Federal Reserve Bank. If there is no duration equivalent Treasury security available to match the duration of the 
Log yield spread

Bond rating

Public bond issue

Principal amount

Floating

Callable

Putable

Duration

Convexity

Time-to-maturity

Total assets

Log total assets

MTBV

MTBV missing

ROA

Leverage

Cross-list corporate bond, the yield to maturity on the Treasury security is calculated as the linear interpolation between the two closest maturity matches. We measure the bond yield spread for a floating rate bond as the difference between the reference index and the yield on its corresponding equivalent Treasury security over the first interest period and add the bond's basis point spread. Source: SDC.

Logarithm of yield spread.

We code Standard \& Poors bond ratings as in Appendix A. Source: SDC.

Dummy variable equals one if the bond is issued in the public marketplace, and zero otherwise. Source: SDC.

Amount borrowed in million U.S. dollars. Source: SDC.

Dummy variable equals one if the bond's coupon is floating, and zero otherwise. Source: SDC.

Dummy variable equals one if the bond is callable, and zero otherwise. Source: SDC.

Dummy variable equals one if the bond is putable, and zero otherwise. Source: SDC.

The bond's Macauley duration, calculated following Fabozzi (2000). Source: SDC.

The bond's convexity, calculated as the second derivative of the bond price with respect to the bond yield following Fabozzi (2000). Source: SDC.

Time-to-maturity of the bond in question (in years). Source: SDC.

\section{E. Firm specific variables}

Total assets in U.S. dollars. Source: Worldscope.

Logarithm of total assets.

Market-to-book value defined as the market capitalization of stock plus total debt divided by total assets. Missing market-to-book values are replaced with the sample average. Source: Worldscope.

Dummy variable equals one if the market-to-book value is missing, and zero otherwise.

Return-on-assets defined as net income divided by total assets. Source: Worldscope.

Financial leverage defined as the sum of long and short term debt divided by total assets. Source: Worldscope.

Dummy variable equals one if the firm in question participates in an ADR program at the time of the bond issue, and zero otherwise. Source: Bank of New York, Citigroup, and JP Morgan. 


\section{Table II}

\section{Number of Eurobonds}

The table reports the number of Eurobonds across time and for different countries. All bonds are denominated in U.S. dollars. The sample period is 1980 to 2006 and the data are from SDC.

\begin{tabular}{|c|c|c|c|c|}
\hline \multirow[t]{2}{*}{ Country } & \multicolumn{4}{|c|}{ Eurobonds } \\
\hline & $1980 \mathrm{~s}$ & 1990s & $2000 \mathrm{~s}$ & Total \\
\hline Argentina & 0 & 5 & 1 & 6 \\
\hline Australia & 0 & 85 & 129 & 214 \\
\hline Austria & 0 & 5 & 7 & 12 \\
\hline Belgium & 2 & 33 & 25 & 60 \\
\hline Brazil & 0 & 4 & 22 & 26 \\
\hline Canada & 7 & 58 & 51 & 116 \\
\hline Chile & 0 & 1 & 1 & 2 \\
\hline China & 0 & 0 & 1 & 1 \\
\hline Denmark & 2 & 10 & 8 & 20 \\
\hline Finland & 0 & 4 & 2 & 6 \\
\hline France & 2 & 60 & 54 & 116 \\
\hline Germany & 0 & 126 & 87 & 213 \\
\hline Greece & 0 & 3 & 2 & 5 \\
\hline Hong Kong & 0 & 4 & 17 & 21 \\
\hline India & 0 & 6 & 1 & 7 \\
\hline Indonesia & 0 & 1 & 1 & 2 \\
\hline Ireland & 3 & 5 & 13 & 21 \\
\hline Israel & 0 & 1 & 0 & 1 \\
\hline Italy & 0 & 22 & 16 & 38 \\
\hline Japan & 34 & 147 & 50 & 231 \\
\hline Malaysia & 0 & 1 & 8 & 9 \\
\hline Mexico & 0 & 3 & 17 & 20 \\
\hline Netherlands & 1 & 34 & 40 & 75 \\
\hline New Zealand & 0 & 1 & 1 & 2 \\
\hline Norway & 0 & 10 & 23 & 33 \\
\hline Philippines & 0 & 1 & 4 & 5 \\
\hline Poland & 0 & 3 & 0 & 3 \\
\hline Portugal & 0 & 7 & 4 & 11 \\
\hline Russia & 0 & 0 & 9 & 9 \\
\hline Singapore & 0 & 0 & 8 & 8 \\
\hline South Africa & 0 & 0 & 1 & 1 \\
\hline South Korea & 0 & 19 & 26 & 45 \\
\hline Spain & 0 & 31 & 26 & 57 \\
\hline Sweden & 2 & 35 & 23 & 60 \\
\hline Switzerland & 0 & 31 & 33 & 64 \\
\hline Thailand & 0 & 5 & 3 & 8 \\
\hline Turkey & 0 & 0 & 2 & 2 \\
\hline United Kingdom & 4 & 73 & 103 & 180 \\
\hline United States & 44 & 486 & 269 & 799 \\
\hline Total & 101 & 1,320 & 1,088 & 2,509 \\
\hline
\end{tabular}


Table III

Descriptive statistics by countries

The table reports means for the variables used in our main regressions for Eurobonds. The variables are described in Table I. The sample period is 1980 to 2006.

\begin{tabular}{|c|c|c|c|c|c|c|c|c|c|c|c|c|c|c|c|c|}
\hline Country & $\begin{array}{c}\text { Yield } \\
\text { spread }\end{array}$ & $\begin{array}{l}\text { Bond } \\
\text { rating }\end{array}$ & $\begin{array}{c}\text { Political } \\
\text { rights }\end{array}$ & SPI & $\begin{array}{l}\text { Freedom } \\
\text { of the } \\
\text { press }\end{array}$ & $\begin{array}{l}\text { Corrup- } \\
\text { tion }\end{array}$ & $\begin{array}{c}\text { Expro- } \\
\text { priation }\end{array}$ & $\begin{array}{l}\text { Creditor } \\
\text { rights }\end{array}$ & $\begin{array}{c}\text { Real } \\
\text { GDP per } \\
\text { capita }\end{array}$ & $\begin{array}{l}\text { Sovereign } \\
\text { rating }\end{array}$ & $\begin{array}{l}\text { Principal } \\
\text { amount }\end{array}$ & $\begin{array}{l}\text { Time-to- } \\
\text { maturity }\end{array}$ & Public & Floating & ROA & Obs. \\
\hline Argentina & 426.4 & 8.2 & 5.83 & 2.00 & 6.72 & 5.42 & 3.69 & 1.00 & 7,629 & 9.0 & 131.7 & 3.7 & 0.667 & 0.167 & 0.030 & 6 \\
\hline Australia & 67.1 & 16.4 & 7.00 & -0.70 & 8.87 & 2.56 & 0.62 & 3.00 & 20,373 & 20.1 & 282.4 & 5.8 & 0.902 & 0.832 & 0.012 & 214 \\
\hline Austria & 40.1 & 19.4 & 7.00 & -0.69 & 8.56 & 2.21 & 0.26 & 3.00 & 22,882 & 21.0 & 223.5 & 4.8 & 1.000 & 0.333 & 0.003 & 12 \\
\hline Belgium & 63.6 & 18.2 & 7.00 & -0.63 & 9.05 & 2.57 & 0.31 & 2.00 & 21,481 & 20.0 & 221.7 & 5.3 & 1.000 & 0.333 & 0.012 & 60 \\
\hline Brazil & 368.8 & 10.0 & 5.54 & -0.19 & 6.57 & 7.45 & 2.12 & 1.00 & 3,439 & 8.5 & 206.4 & 3.7 & 0.462 & 0.077 & 0.035 & 26 \\
\hline Canada & 105.0 & 15.7 & 7.00 & -0.67 & 8.56 & 2.01 & 0.28 & 1.07 & 21,898 & 20.1 & 311.9 & 5.0 & 0.853 & 0.698 & 0.008 & 116 \\
\hline Chile & 172.7 & 12.0 & 6.50 & 0.33 & 7.30 & 4.80 & 2.20 & 2.00 & 5,333 & 15.5 & 200.0 & 20.0 & 0.000 & 0.000 & 0.075 & 2 \\
\hline China & 370.4 & 8.0 & 1.00 & -0.98 & 1.70 & N/A & 1.89 & 2.00 & 1,579 & 16.0 & 200.0 & 7.0 & 1.000 & 0.000 & 0.056 & 1 \\
\hline Denmark & 82.2 & 16.1 & 7.00 & -0.72 & 9.06 & 2.55 & 0.28 & 3.00 & 28,489 & 20.5 & 167.0 & 4.9 & 0.850 & 0.750 & 0.012 & 20 \\
\hline Finland & 54.5 & 12.5 & 7.00 & -0.74 & 8.62 & 1.20 & 0.28 & 1.00 & 20,460 & 19.2 & 208.3 & 6.7 & 0.833 & 0.833 & 0.008 & 6 \\
\hline France & 115.9 & 15.5 & 7.00 & -0.32 & 7.77 & 2.77 & 0.29 & 0.00 & 21,362 & 21.0 & 230.8 & 5.5 & 0.931 & 0.466 & 0.018 & 116 \\
\hline Germany & 72.2 & 17.6 & 7.00 & -0.58 & 8.67 & 2.19 & 0.11 & 3.00 & 22,153 & 21.0 & 259.0 & 4.5 & 0.981 & 0.390 & 0.008 & 213 \\
\hline Greece & 113.5 & 12.2 & 7.00 & 0.05 & 8.28 & 6.32 & 2.52 & 1.00 & 10,222 & 14.2 & 346.0 & 4.4 & 0.800 & 0.600 & 0.007 & 5 \\
\hline Hong Kong & 266.7 & 11.6 & 1.86 & N/A & 6.84 & 2.78 & 1.51 & 4.00 & 26,355 & 17.0 & 370.7 & 8.3 & 0.571 & 0.095 & 0.042 & 21 \\
\hline India & 212.7 & 9.9 & 5.71 & 1.03 & 5.46 & 9.76 & 1.93 & 2.00 & 413 & 11.0 & 150.0 & 14.6 & 0.429 & 0.143 & 0.047 & 7 \\
\hline Indonesia & 379.4 & 8.5 & 3.00 & -0.17 & 3.50 & 9.65 & 2.53 & 2.50 & 808 & 6.5 & 202.5 & 5.0 & 0.500 & 0.000 & 0.046 & 2 \\
\hline Ireland & 77.5 & 15.3 & 7.00 & -0.67 & 8.38 & 3.96 & 0.28 & 1.14 & 24,337 & 19.7 & 357.5 & 5.2 & 0.810 & 0.857 & 0.008 & 21 \\
\hline Israel & 73.5 & 14.0 & 7.00 & -0.06 & 7.20 & 8.00 & 1.49 & 3.00 & 18,311 & 15.0 & 200.0 & 5.0 & 1.000 & 1.000 & 0.007 & 1 \\
\hline Italy & 110.9 & 14.4 & 7.00 & 0.80 & 7.36 & 4.38 & 0.54 & 2.00 & 17,960 & 18.5 & 312.6 & 6.4 & 0.842 & 0.842 & 0.002 & 38 \\
\hline Japan & 45.1 & 18.4 & 6.84 & -0.64 & 8.44 & 2.26 & 0.28 & 2.66 & 35,176 & 20.5 & 290.3 & 4.8 & 0.957 & 0.221 & 0.018 & 231 \\
\hline Malaysia & 164.1 & 10.9 & 3.67 & -0.64 & 3.09 & 5.81 & 1.85 & 3.00 & 4,367 & 15.0 & 250.6 & 12.4 & 0.889 & 0.111 & 0.028 & 9 \\
\hline Mexico & 379.2 & 9.2 & 5.85 & 2.51 & 5.77 & 7.20 & 2.53 & 0.00 & 5,882 & 12.2 & 290.8 & 7.6 & 0.150 & 0.050 & 0.051 & 20 \\
\hline Netherlands & 152.9 & 16.2 & 7.00 & -0.71 & 8.61 & 2.04 & 0.02 & 3.00 & 22,180 & 21.0 & 299.1 & 5.8 & 0.880 & 0.387 & 0.009 & 75 \\
\hline New Zealand & 106.5 & 16.5 & 7.00 & -0.75 & 9.20 & 2.00 & 0.26 & 4.00 & 13,414 & 19.5 & 173.5 & 10.1 & 1.000 & 0.000 & 0.067 & 2 \\
\hline Norway & 108.0 & 14.3 & 7.00 & -0.71 & 9.41 & 2.06 & 0.15 & 2.00 & 38,090 & 21.0 & 274.3 & 5.6 & 0.909 & 0.818 & 0.010 & 33 \\
\hline Philippines & 510.8 & 8.6 & 5.60 & 3.51 & 6.40 & 8.60 & 4.21 & 1.00 & 968 & 10.0 & 175.0 & 7.0 & 0.400 & 0.000 & 0.028 & 5 \\
\hline Poland & 523.5 & 8.7 & 7.00 & -0.63 & 7.50 & 6.00 & 2.19 & 1.00 & 4,089 & 13.3 & 150.0 & 8.4 & 1.000 & 0.000 & -0.015 & 3 \\
\hline Portugal & 78.0 & 13.6 & 7.00 & -0.31 & 8.31 & 4.00 & 0.99 & 1.00 & 9,586 & 18.5 & 300.0 & 2.3 & 1.000 & 1.000 & 0.007 & 11 \\
\hline Russia & 555.9 & 7.3 & 2.22 & 0.52 & 3.43 & 8.43 & 1.50 & 2.00 & 2,248 & 10.8 & 361.1 & 6.0 & 0.333 & 0.000 & 0.112 & 9 \\
\hline Singapore & 144.8 & 13.8 & 3.00 & -0.67 & 3.50 & 1.79 & 0.61 & 3.00 & 23,020 & 21.0 & 698.8 & 10.0 & 0.375 & 0.250 & 0.006 & 8 \\
\hline South Africa & 186.0 & 12.0 & 7.00 & 0.14 & 7.70 & 6.00 & 2.65 & 3.00 & 3,182 & 12.0 & 250.0 & 30.0 & 0.000 & 0.000 & 0.048 & 1 \\
\hline
\end{tabular}


Table III continued - Descriptive statistics by countries

\begin{tabular}{|c|c|c|c|c|c|c|c|c|c|c|c|c|c|c|c|c|}
\hline Country & $\begin{array}{c}\text { Yield } \\
\text { spread }\end{array}$ & $\begin{array}{l}\text { Bond } \\
\text { rating }\end{array}$ & $\begin{array}{c}\text { Political } \\
\text { rights }\end{array}$ & SPI & $\begin{array}{c}\text { Freedom } \\
\text { of the } \\
\text { press }\end{array}$ & $\begin{array}{c}\text { Corrup- } \\
\text { tion }\end{array}$ & $\begin{array}{c}\text { Expro- } \\
\text { priation }\end{array}$ & $\begin{array}{c}\text { Creditor } \\
\text { rights }\end{array}$ & $\begin{array}{c}\text { Real } \\
\text { GDP per } \\
\text { capita }\end{array}$ & $\begin{array}{l}\text { Sovereign } \\
\text { rating }\end{array}$ & $\begin{array}{c}\text { Principal } \\
\text { amount }\end{array}$ & $\begin{array}{l}\text { Time-to- } \\
\text { maturity }\end{array}$ & Public & Floating & ROA & Obs. \\
\hline South Korea & 175.6 & 12.6 & 6.29 & 0.16 & 7.30 & 5.14 & 1.43 & 3.00 & 10,960 & 15.7 & 251.1 & 6.0 & 0.689 & 0.489 & 0.014 & 45 \\
\hline Spain & 98.3 & 16.0 & 7.00 & 1.45 & 8.13 & 4.45 & 0.45 & 2.00 & 13,678 & 19.9 & 273.9 & 5.3 & 0.930 & 0.789 & 0.011 & 57 \\
\hline Sweden & 51.7 & 16.2 & 7.00 & -0.67 & 9.00 & 1.95 & 0.50 & 1.28 & 24,971 & 20.3 & 243.0 & 3.8 & 0.933 & 0.633 & 0.018 & 60 \\
\hline Switzerland & 49.6 & 17.8 & 7.00 & -0.72 & 9.09 & 2.14 & 0.01 & 1.00 & 32,782 & 21.0 & 276.0 & 6.5 & 0.922 & 0.406 & 0.029 & 64 \\
\hline Thailand & 106.8 & 12.5 & 4.00 & -0.01 & 5.80 & 5.31 & 2.36 & 2.63 & 2,245 & 15.3 & 231.3 & 5.6 & 0.625 & 0.375 & 0.015 & 8 \\
\hline Turkey & 254.5 & 16.0 & 4.50 & 2.22 & 4.50 & 6.90 & 2.71 & 2.00 & 3,181 & 8.5 & 150.0 & 6.5 & 0.500 & 0.500 & 0.017 & 2 \\
\hline UK & 54.7 & 17.5 & 7.00 & 0.62 & 8.11 & 2.13 & 0.24 & 4.00 & 23,668 & 21.0 & 338.2 & 4.9 & 0.906 & 0.494 & 0.015 & 180 \\
\hline United States & 100.3 & 16.1 & 7.00 & -0.57 & 8.67 & 2.33 & 0.02 & 1.00 & 32,568 & 21.0 & 299.1 & 6.5 & 0.785 & 0.382 & 0.025 & 799 \\
\hline Total & 100.8 & 16.2 & 6.84 & -0.37 & 8.40 & 2.66 & 0.33 & 1.92 & 25,929 & 20.2 & 286.3 & 5.7 & 0.852 & 0.459 & 0.018 & 2,509 \\
\hline
\end{tabular}


Table IV

\section{Correlation coefficients}

This table provides correlation coefficients for key variables for Eurobonds. The variables are described in Table I. The sample period is 1980 to 2006. Coefficients in bold are significant at the $5 \%$ level.

\begin{tabular}{|c|c|c|c|c|c|c|c|c|c|c|c|c|c|c|c|c|c|c|}
\hline & \begin{tabular}{|c|} 
Log \\
yield \\
spread
\end{tabular} & $\begin{array}{l}\text { Bond } \\
\text { rating }\end{array}$ & $\begin{array}{l}\text { Political } \\
\text { rights }\end{array}$ & SPI & SPI AP & $\begin{array}{c}\text { Freedom } \\
\text { of the } \\
\text { press }\end{array}$ & $\begin{array}{l}\text { Corrup- } \\
\text { tion }\end{array}$ & $\begin{array}{l}\text { Expro- } \\
\text { priation }\end{array}$ & $\begin{array}{l}\text { Democ- } \\
\text { racy }\end{array}$ & $\begin{array}{l}\text { Creditor } \\
\text { rights }\end{array}$ & $\begin{array}{l}\text { Log real } \\
\text { GDP/cap }\end{array}$ & $\begin{array}{l}\text { Sover- } \\
\text { eign } \\
\text { rating }\end{array}$ & $\begin{array}{l}\text { Cross- } \\
\text { list }\end{array}$ & $\begin{array}{c}\text { Log } \\
\text { total } \\
\text { assets }\end{array}$ & ROA & $\begin{array}{l}\text { Lever- } \\
\text { age }\end{array}$ & Public & Floating \\
\hline Log yield spread & 1.00 & & & & & & & & & & & & & & & & & \\
\hline Bond rating & -0.65 & 1.00 & & & & & & & & & & & & & & & & \\
\hline Political rights & -0.25 & 0.30 & 1.00 & & & & & & & & & & & & & & & \\
\hline SPI & 0.19 & -0.18 & -0.21 & 1.00 & & & & & & & & & & & & & & \\
\hline SPI AP & 0.21 & -0.24 & -0.44 & 0.68 & 1.00 & & & & & & & & & & & & & \\
\hline Freedom of the press & -0.31 & 0.37 & 0.66 & -0.45 & -0.50 & 1.00 & & & & & & & & & & & & \\
\hline Corruption & 0.39 & -0.46 & -0.39 & 0.47 & 0.52 & -0.60 & 1.00 & & & & & & & & & & & \\
\hline Expropriation & 0.33 & -0.39 & -0.55 & 0.50 & 0.66 & -0.62 & 0.71 & 1.00 & & & & & & & & & & \\
\hline Democracy & -0.33 & 0.39 & 0.65 & -0.53 & -0.69 & 0.70 & 0.70 & -0.78 & 1.00 & & & & & & & & & \\
\hline Creditor rights & -0.09 & 0.16 & -0.14 & 0.14 & 0.01 & -0.03 & -0.10 & 0.10 & 0.09 & 1.00 & & & & & & & & \\
\hline Log real GDP/cap & -0.24 & 0.33 & 0.44 & -0.50 & -0.56 & 0.62 & -0.72 & -0.81 & 0.71 & -0.11 & 1.00 & & & & & & & \\
\hline Sovereign rating & -0.34 & 0.42 & 0.52 & -0.41 & -0.61 & 0.63 & -0.81 & -0.88 & 0.74 & 0.03 & 0.81 & 1.00 & & & & & & \\
\hline Cross-list & 0.03 & 0.03 & -0.02 & 0.14 & 0.08 & -0.10 & 0.04 & 0.12 & -0.04 & 0.34 & -0.09 & -0.04 & 1.00 & & & & & \\
\hline Log total assets & -0.34 & 0.47 & 0.28 & -0.09 & -0.13 & 0.21 & -0.28 & -0.35 & 0.28 & 0.05 & 0.24 & 0.32 & 0.13 & 1.00 & & & & \\
\hline ROA & -0.13 & 0.06 & -0.13 & 0.05 & 0.04 & -0.10 & 0.10 & 0.07 & -0.11 & -0.13 & -0.06 & -0.12 & -0.08 & -0.32 & 1.00 & & & \\
\hline Leverage & 0.06 & -0.05 & 0.05 & 0.02 & 0.02 & 0.05 & -0.03 & -0.09 & 0.04 & -0.01 & 0.06 & 0.06 & -0.08 & 0.06 & -0.23 & 1.00 & & \\
\hline Public & -0.46 & 0.48 & 0.15 & -0.10 & -0.12 & 0.26 & -0.36 & -0.19 & 0.22 & 0.13 & 0.08 & 0.22 & -0.01 & 0.31 & -0.06 & -0.04 & 1.00 & \\
\hline Floating & 0.04 & 0.08 & 0.13 & 0.01 & -0.03 & 0.11 & -0.08 & -0.03 & 0.08 & 0.03 & 0.01 & 0.07 & 0.05 & 0.22 & -0.28 & -0.09 & 0.23 & 1.00 \\
\hline
\end{tabular}




\section{Table V}

\section{Descriptive statistics of regression variables}

The table reports mean, median, and standard deviation of the variables employed in the regression analysis for Eurobonds. The variables are described in Table I. The sample period is 1980 to 2006.

\begin{tabular}{lcccc}
\hline Variables & Mean & Median & $\begin{array}{c}\text { Standard } \\
\text { deviation }\end{array}$ & Obs. \\
\hline Yield spread & 100.796 & 54.800 & 169.486 & 2,027 \\
Log yield spread & 3.938 & 4.007 & 1.181 & 2,020 \\
Bond rating & 16.199 & 17.000 & 3.530 & 2,509 \\
Political rights & 6.837 & 7.000 & 0.747 & 2,509 \\
SPI & -0.373 & -0.612 & 0.610 & 2,488 \\
SPI AP & -10.311 & -11.060 & 3.257 & 2,349 \\
Freedom of the press & 8.400 & 8.600 & 0.872 & 2,509 \\
Corruption & 2.665 & 2.000 & 1.337 & 2,471 \\
Expropriation & 0.331 & 0.236 & 0.526 & 2,509 \\
Democracy & 9.426 & 10.000 & 1.735 & 2,488 \\
Creditor rights & 1.919 & 1.000 & 1.138 & 2,509 \\
Real GDP per capita & 25,929 & 24,993 & 8,225 & 2,509 \\
Log real GDP per capita & 10.074 & 10.126 & 0.531 & 2,509 \\
Sovereign rating & 20.170 & 21.000 & 2.202 & 2,498 \\
Cross-list & 0.293 & 0.000 & 0.455 & 2,509 \\
Total assets (in millions) & 207,586 & 119,724 & 245,896 & 2,509 \\
Log total assets & 18.260 & 18.601 & 1.679 & 2,509 \\
MTBV & 2.933 & 0.574 & 20.256 & 2,509 \\
MTBV missing & 0.035 & 0.000 & 0.183 & 2,509 \\
ROA & 0.018 & 0.009 & 0.031 & 2,509 \\
Leverage & 0.354 & 0.344 & 0.172 & 2,509 \\
Public & 0.852 & 1.000 & 0.355 & 2,509 \\
Floating bond & 0.459 & 0.000 & 0.498 & 2,509 \\
Callable & 0.179 & 0.000 & 0.384 & 2,509 \\
Putable & 0.006 & 0.000 & 0.075 & 2,509 \\
Duration & 2.550 & 1.867 & 2.764 & 2,431 \\
Convexity & 18.852 & 4.963 & 54.731 & 2,431 \\
\hline
\end{tabular}




\section{Table VI \\ Bond rating and political and legal institutions}

The table shows regression estimates of bond rating on political and legal conditions, firm controls, and bond characteristics for Eurobonds (equations (1) and (3) in the text). The variable political rights $\times$ creditor rights is the residuals from regressing the interaction between political rights and creditor rights on its individual variables. The variables are described in Table I and the sample period is 1980 to 2006. The models are estimated with OLS and include year and two-digit industry dummy variables (not reported). Standard errors are robust and corrected for clustering by firm; the associated t-statistics are reported in parentheses. a, b, and c denote significance at the $10 \%$, $5 \%$, and $1 \%$ levels, respectively.

\begin{tabular}{|c|c|c|c|c|c|c|}
\hline \multirow[t]{2}{*}{ Independent variables } & \multicolumn{6}{|c|}{ Dependent variable: Bond rating } \\
\hline & (1) & (2) & (3) & (4) & (5) & (6) \\
\hline Political rights & $\begin{array}{c}0.528^{\mathrm{c}} \\
(4.40)\end{array}$ & $\begin{array}{c}0.556^{\mathbf{c}} \\
(4.51)\end{array}$ & $\begin{array}{c}0.413^{\mathrm{c}} \\
(3.54)\end{array}$ & $\begin{array}{c}0.586^{c} \\
(4.15)\end{array}$ & $\begin{array}{c}0.481^{\mathrm{b}} \\
(2.00)\end{array}$ & \\
\hline Socio-political instability & & & & & $\begin{array}{l}-0.117 \\
(-0.68)\end{array}$ & $\begin{array}{l}0.001 \\
(0.01)\end{array}$ \\
\hline Freedom of the press & & & & & $\begin{array}{c}0.030 \\
(0.14)\end{array}$ & $\begin{array}{l}0.265 \\
(1.56)\end{array}$ \\
\hline Corruption & & & & & $\begin{array}{l}-0.468^{\mathrm{C}} \\
(-4.24)\end{array}$ & $\begin{array}{c}-0.468^{\mathrm{C}} \\
(-4.19)\end{array}$ \\
\hline Expropriation risk & & & & & $\begin{array}{c}0.129 \\
(0.36)\end{array}$ & $\begin{array}{l}0.072 \\
(0.20)\end{array}$ \\
\hline Creditor rights & $\begin{array}{c}0.640^{c} \\
(6.58)\end{array}$ & $\begin{array}{c}0.576^{\mathbf{c}} \\
(6.01)\end{array}$ & $\begin{array}{c}0.508^{\mathrm{C}} \\
(5.41)\end{array}$ & $\begin{array}{c}0.574^{\mathrm{C}} \\
(6.04)\end{array}$ & $\begin{array}{c}0.521^{\mathrm{c}} \\
(5.33)\end{array}$ & $\begin{array}{c}0.508^{c} \\
(5.27)\end{array}$ \\
\hline Political rights $\times$ Creditor rights & & & & $\begin{array}{c}-0.075 \\
(-0.71) \\
\end{array}$ & & \\
\hline Log GDP per capita & $\begin{array}{c}1.165^{* * *} \\
(6.33)\end{array}$ & $\begin{array}{l}1.065^{\mathrm{c}} \\
(5.68)\end{array}$ & $\begin{array}{l}0.144 \\
(0.46)\end{array}$ & $\begin{array}{c}0.968^{\mathrm{C}} \\
(4.08)\end{array}$ & $\begin{array}{l}0.269 \\
(0.58)\end{array}$ & $\begin{array}{l}0.351 \\
(0.73)\end{array}$ \\
\hline Sovereign rating & & & $\begin{array}{c}0.300^{\mathrm{c}} \\
(3.78) \\
\end{array}$ & & & \\
\hline Log total assets & $\begin{array}{c}0.819^{c} \\
(8.65)\end{array}$ & $\begin{array}{c}0.740^{c} \\
(8.23)\end{array}$ & $\begin{array}{c}0.707^{c} \\
(7.94)\end{array}$ & $\begin{array}{c}0.745^{\mathrm{C}} \\
(8.19)\end{array}$ & $\begin{array}{c}0.710^{c} \\
(7.44)\end{array}$ & $\begin{array}{c}0.717^{\mathrm{C}} \\
(7.53)\end{array}$ \\
\hline MTBV & $\begin{array}{l}0.000 \\
(0.078)\end{array}$ & $\begin{array}{l}0.001 \\
(0.33)\end{array}$ & $\begin{array}{c}0.002 \\
(0.69)\end{array}$ & $\begin{array}{l}0.001 \\
(0.38)\end{array}$ & $\begin{array}{c}0.001 \\
(0.37)\end{array}$ & $\begin{array}{l}0.001 \\
(0.42)\end{array}$ \\
\hline MTBV missing & $\begin{array}{c}-0.743 \\
(-1.17)\end{array}$ & $\begin{array}{c}-0.746 \\
(-1.24)\end{array}$ & $\begin{array}{c}-0.831 \\
(-1.44)\end{array}$ & $\begin{array}{l}-0.737 \\
(-1.23)\end{array}$ & $\begin{array}{l}-0.837 \\
(-1.40)\end{array}$ & $\begin{array}{c}-0.820 \\
(-1.35)\end{array}$ \\
\hline ROA & $\begin{array}{c}26.715^{\mathrm{c}} \\
(6.82)\end{array}$ & $\begin{array}{c}25.765^{\mathrm{c}} \\
(6.67)\end{array}$ & $\begin{array}{c}25.956^{\mathrm{c}} \\
(6.69)\end{array}$ & $\begin{array}{c}25.872^{\mathrm{C}} \\
(6.66)\end{array}$ & $\begin{array}{c}27.530^{c} \\
(6.77)\end{array}$ & $\begin{array}{c}27.082^{\mathrm{c}} \\
(6.67)\end{array}$ \\
\hline Leverage & $\begin{array}{c}-0.395 \\
(-0.54)\end{array}$ & $\begin{array}{c}-0.178 \\
(-0.25)\end{array}$ & $\begin{array}{c}-0.316 \\
(-0.44)\end{array}$ & $\begin{array}{c}-0.187 \\
(-0.26)\end{array}$ & $\begin{array}{c}0.083 \\
(0.12)\end{array}$ & $\begin{array}{l}0.063 \\
(0.088)\end{array}$ \\
\hline Public bond issue & & $\begin{array}{c}2.187^{c} \\
(5.76)\end{array}$ & $\begin{array}{c}2.101^{c} \\
(5.51)\end{array}$ & $\begin{array}{c}2.184^{\mathrm{C}} \\
(5.74)\end{array}$ & $\begin{array}{c}2.129^{c} \\
(5.48)\end{array}$ & $\begin{array}{c}2.115^{c} \\
(5.44)\end{array}$ \\
\hline Floating bond & & $\begin{array}{c}-0.043 \\
(-0.18)\end{array}$ & $\begin{array}{c}-0.073 \\
(-0.31) \\
\end{array}$ & $\begin{array}{c}-0.050 \\
(-0.21) \\
\end{array}$ & $\begin{array}{l}0.013 \\
(0.056)\end{array}$ & $\begin{array}{c}0.026 \\
(0.11)\end{array}$ \\
\hline Observations & 2,509 & 2,509 & 2,498 & 2,509 & 2,450 & 2,450 \\
\hline Adjusted R-squared & 0.550 & 0.572 & 0.583 & 0.572 & 0.582 & 0.581 \\
\hline Log likelihood & $-5,682$ & $-5,619$ & $-5,562$ & $-5,618$ & $-5,443$ & $-5,448$ \\
\hline
\end{tabular}




\section{Table VII \\ Bond yield spreads and political and legal institutions}

The table shows regression estimates of log yield spreads on political and legal conditions, firm controls, and bond characteristics for Eurobonds (equations (2) and (4) in the text). The variable political rights $\times$ creditor rights is the residual from regressing the interaction between political rights and creditor rights on the individual variables. The variable residuals of bond rating represents the residuals of a regression of bond rating on political and legal conditions employed in the specification under investigation. More specifically, it refers to the residuals ( $\varepsilon_{\mathrm{i}}$ ) of the following regressions (i indicates a specific bond issue; year and industry dummy variables are included but not reported):

Columns:

(1) to (3) $\quad$ Bond rating $_{\mathrm{i}}=\beta_{0}+\beta_{1}$ Political rights $_{\mathrm{i}}+\beta_{2}$ Creditor rights $_{\mathrm{i}}+\varepsilon_{\mathrm{i}}$

$$
\begin{aligned}
& \text { Bond rating }_{\mathrm{i}}=\beta_{0}+\beta_{1} \text { Political rights }_{\mathrm{i}}+\beta_{2} \text { Creditor rights }_{\mathrm{i}}+\beta_{3}\left(\text { Political rights }_{\mathrm{i}} \times \text { Creditor rights }_{\mathrm{i}}\right)+\varepsilon_{\mathrm{i}} \\
& \text { Bond rating }_{\mathrm{i}}=\beta_{0}+\beta_{1} \text { Political rights }_{\mathrm{i}}+\beta_{2} \text { Socio-political instability }_{\mathrm{i}}+\beta_{3} \text { Freedom of the press }_{\mathrm{i}}+
\end{aligned}
$$

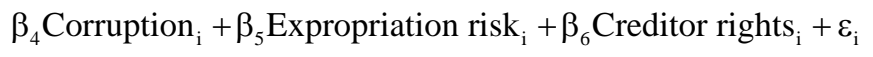

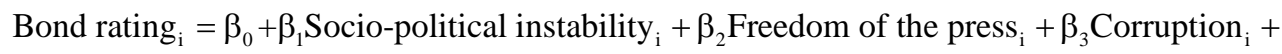

$$
\begin{aligned}
& \beta_{4} \text { Expropriation risk }_{\mathrm{i}}+\beta_{5} \text { Creditor rights }_{\mathrm{i}}+\varepsilon_{\mathrm{i}}
\end{aligned}
$$

All other variables are described in Table I and the sample period is 1980 to 2006. The models are estimated with OLS and include year and two-digit industry dummy variables (not reported). Standard errors are robust and corrected for clustering by firm; the associated t-statistics are reported in parentheses. a, b, and c denote significance at the $10 \%, 5 \%$, and $1 \%$ levels, respectively. 
Table VII continued - Bond yield spreads and political and legal institutions

\begin{tabular}{|c|c|c|c|c|c|c|}
\hline \multirow[t]{2}{*}{ Independent variables } & \multicolumn{6}{|c|}{ Dependent variable: Log yield spread } \\
\hline & $(1)$ & $(2)$ & (3) & (4) & (5) & (6) \\
\hline Political rights & $\begin{array}{c}-0.253^{C} \\
(-10.1)\end{array}$ & $\begin{array}{c}-0.249^{\mathrm{C}} \\
(-9.66)\end{array}$ & $\begin{array}{c}-0.216^{\mathrm{C}} \\
(-7.96)\end{array}$ & $\begin{array}{c}-0.269^{\mathrm{C}} \\
(-9.41)\end{array}$ & $\begin{array}{c}-0.151^{\mathbf{b}} \\
(-2.22)\end{array}$ & \\
\hline Socio-political instability & & & & & $\begin{array}{c}0.066^{\mathrm{a}} \\
(1.70)\end{array}$ & $\begin{array}{c}0.028 \\
(0.82)\end{array}$ \\
\hline Freedom of the press & & & & & $\begin{array}{c}-0.006 \\
(-0.14)\end{array}$ & $\begin{array}{c}-0.083^{\mathrm{C}} \\
(-3.10)\end{array}$ \\
\hline Corruption & & & & & $\begin{array}{c}0.137^{\mathrm{C}} \\
(5.93)\end{array}$ & $\begin{array}{c}0.139^{\mathrm{c}} \\
(5.98)\end{array}$ \\
\hline Expropriation risk & & & & & $\begin{array}{c}0.245^{\mathrm{C}} \\
(3.36)\end{array}$ & $\begin{array}{c}0.271^{\mathrm{C}} \\
(3.58)\end{array}$ \\
\hline Creditor rights & $\begin{array}{c}-0.145^{\mathrm{C}} \\
(-6.87)\end{array}$ & $\begin{array}{c}-0.113^{\mathrm{C}} \\
(-5.89)\end{array}$ & $\begin{array}{c}-0.094^{\mathrm{C}} \\
(-4.64)\end{array}$ & $\begin{array}{c}-0.109^{\mathrm{c}} \\
(-5.66)\end{array}$ & $\begin{array}{c}-0.098^{\mathrm{C}} \\
(-4.95)\end{array}$ & $\begin{array}{c}-0.093^{\mathbf{c}} \\
(-4.85)\end{array}$ \\
\hline Political rights $\times$ Creditor rights & & & & $\begin{array}{c}0.103^{\mathrm{C}} \\
(4.97)\end{array}$ & & \\
\hline Log GDP per capita & $\begin{array}{c}-0.162^{\mathrm{C}} \\
(-4.04)\end{array}$ & $\begin{array}{c}-0.200^{\mathrm{C}} \\
(-4.94)\end{array}$ & $\begin{array}{c}-0.014 \\
(-0.25)\end{array}$ & $\begin{array}{c}-0.141^{\mathrm{C}} \\
(-3.01)\end{array}$ & $\begin{array}{l}0.037 \\
(0.50)\end{array}$ & $\begin{array}{c}0.025 \\
(0.34)\end{array}$ \\
\hline Sovereign rating & & & $\begin{array}{c}-0.061^{\mathrm{c}} \\
(-3.74) \\
\end{array}$ & & & \\
\hline Log total assets & $\begin{array}{c}-0.034^{\mathbf{b}} \\
(-2.02)\end{array}$ & $\begin{array}{c}-0.011 \\
(-0.74)\end{array}$ & $\begin{array}{c}-0.006 \\
(-0.44)\end{array}$ & $\begin{array}{l}-0.015 \\
(-0.99)\end{array}$ & $\begin{array}{c}-0.006 \\
(-0.42)\end{array}$ & $\begin{array}{r}-0.007 \\
(-0.47)\end{array}$ \\
\hline MTBV & $\begin{array}{c}-0.001 \\
(-0.68)\end{array}$ & $\begin{array}{c}-0.001 \\
(-0.71)\end{array}$ & $\begin{array}{c}-0.002 \\
(-0.84)\end{array}$ & $\begin{array}{c}-0.001 \\
(-0.77)\end{array}$ & $\begin{array}{c}-0.001 \\
(-0.78)\end{array}$ & $\begin{array}{c}-0.001 \\
(-0.81)\end{array}$ \\
\hline MTBV missing & $\begin{array}{c}0.056 \\
(0.39)\end{array}$ & $\begin{array}{c}0.023 \\
(0.21)\end{array}$ & $\begin{array}{c}0.048 \\
(0.46)\end{array}$ & $\begin{array}{l}0.016 \\
(0.15)\end{array}$ & $\begin{array}{l}0.067 \\
(0.65)\end{array}$ & $\begin{array}{c}0.061 \\
(0.59)\end{array}$ \\
\hline ROA & $\begin{array}{c}-3.702^{\mathrm{C}} \\
(-4.89)\end{array}$ & $\begin{array}{c}-3.228^{\mathrm{c}} \\
(-4.35)\end{array}$ & $\begin{array}{c}-3.363^{\mathrm{C}} \\
(-4.52)\end{array}$ & $\begin{array}{c}-3.311^{\mathrm{c}} \\
(-4.43)\end{array}$ & $\begin{array}{c}-3.597^{\mathrm{C}} \\
(-4.61)\end{array}$ & $\begin{array}{c}-3.487^{\mathrm{c}} \\
(-4.44)\end{array}$ \\
\hline Leverage & $\begin{array}{c}-0.021 \\
(-0.16) \\
\end{array}$ & $\begin{array}{c}0.060 \\
(0.46)\end{array}$ & $\begin{array}{c}0.091 \\
(0.71) \\
\end{array}$ & $\begin{array}{c}0.072 \\
(0.56)\end{array}$ & $\begin{array}{c}0.058 \\
(0.45)\end{array}$ & $\begin{array}{c}0.060 \\
(0.46)\end{array}$ \\
\hline Public bond issue & & $\begin{array}{c}-0.405^{\mathrm{C}} \\
(-5.16)\end{array}$ & $\begin{array}{c}-0.392^{\mathrm{C}} \\
(-5.00)\end{array}$ & $\begin{array}{c}-0.396^{\mathbf{C}} \\
(-5.06)\end{array}$ & $\begin{array}{c}-0.377^{\mathrm{C}} \\
(-4.65)\end{array}$ & $\begin{array}{c}-0.375^{\mathrm{c}} \\
(-4.64)\end{array}$ \\
\hline Floating bond & & $\begin{array}{c}0.472^{\mathrm{C}} \\
(3.70)\end{array}$ & $\begin{array}{c}0.505^{c} \\
(3.90)\end{array}$ & $\begin{array}{c}0.491^{\mathrm{c}} \\
(3.82)\end{array}$ & $\begin{array}{c}0.489^{c} \\
(4.03)\end{array}$ & $\begin{array}{c}0.486^{\mathrm{C}} \\
(4.00)\end{array}$ \\
\hline Callable & & $\begin{array}{c}0.317^{\mathrm{c}} \\
(7.03)\end{array}$ & $\begin{array}{c}0.324^{\mathrm{c}} \\
(7.19)\end{array}$ & $\begin{array}{c}0.318^{\mathrm{c}} \\
(7.08)\end{array}$ & $\begin{array}{c}0.330^{\mathrm{c}} \\
(7.37)\end{array}$ & $\begin{array}{c}0.330^{\mathrm{C}} \\
(7.38)\end{array}$ \\
\hline Putable & & $\begin{array}{c}-0.124 \\
(-0.62)\end{array}$ & $\begin{array}{c}-0.127 \\
(-0.59)\end{array}$ & $\begin{array}{c}-0.101 \\
(-0.51)\end{array}$ & $\begin{array}{c}-0.061 \\
(-0.34)\end{array}$ & $\begin{array}{c}-0.063 \\
(-0.34)\end{array}$ \\
\hline Duration & & $\begin{array}{c}0.065^{\mathrm{a}} \\
(1.91)\end{array}$ & $\begin{array}{c}0.072^{\mathbf{b}} \\
(2.06)\end{array}$ & $\begin{array}{c}0.070^{\mathbf{b}} \\
(2.03)\end{array}$ & $\begin{array}{c}0.070^{\mathbf{b}} \\
(2.09)\end{array}$ & $\begin{array}{c}0.070^{\mathbf{b}} \\
(2.10)\end{array}$ \\
\hline Convexity & & $\begin{array}{c}-0.000 \\
(-0.18)\end{array}$ & $\begin{array}{c}-0.000 \\
(-0.21)\end{array}$ & $\begin{array}{c}-0.000 \\
(-0.23)\end{array}$ & $\begin{array}{c}-0.000 \\
(-0.22)\end{array}$ & $\begin{array}{c}-0.000 \\
(-0.26)\end{array}$ \\
\hline Residuals of bond rating & $\begin{array}{c}-0.177^{\mathrm{C}} \\
(-18.4) \\
\end{array}$ & $\begin{array}{c}-0.155^{\mathrm{c}} \\
(-17.4) \\
\end{array}$ & $\begin{array}{c}-0.150^{\mathrm{c}} \\
(-17.1) \\
\end{array}$ & $\begin{array}{c}-0.154^{\mathrm{c}} \\
(-17.3) \\
\end{array}$ & $\begin{array}{c}-0.151^{\mathrm{c}} \\
(-17.4)^{\mathrm{C}} \\
\end{array}$ & $\begin{array}{c}-0.152^{\mathrm{C}} \\
(-17.8) \\
\end{array}$ \\
\hline Observations & 2,020 & 2,020 & 2,017 & 2,020 & 1,973 & 1,973 \\
\hline Adjusted R-squared & 0.550 & 0.582 & 0.586 & 0.583 & 0.585 & 0.585 \\
\hline Log likelihood & $-2,355$ & $-2,277$ & $-2,265$ & $-2,275$ & $-2,206$ & $-2,207$ \\
\hline
\end{tabular}


Table VIII

Robustness tests with alternative variables

The table presents robustness tests for Eurobonds using alternative specifications to those reported in Table VII. It shows regression estimates of log yield spreads (dependent variable) on political and legal conditions, firm controls, and bond characteristics. All variables are described in Table I. The sample period is 1980 to 2006. The models are estimated with OLS and include year and two-digit industry dummy variables (not reported). Standard errors are robust and corrected for clustering by firm; the associated t-statistics are reported in parentheses. a, b, and c denote significance at the $10 \%$, 5\%, and $1 \%$ levels, respectively.

\begin{tabular}{|c|c|c|c|c|c|c|c|c|c|c|}
\hline \multirow[t]{2}{*}{ Independent variables } & \multicolumn{3}{|c|}{ Legal origin } & \multicolumn{2}{|c|}{ Democracy score } & \multicolumn{2}{|c|}{ SPI AP } & \multicolumn{3}{|c|}{ Cross-list } \\
\hline & (1) & (2) & (3) & (4) & (5) & (6) & (7) & (8) & (9) & $(10)$ \\
\hline French legal origin & $\begin{array}{c}0.185^{\mathbf{b}} \\
(2.33)\end{array}$ & $\begin{array}{l}-0.004 \\
(-0.044)\end{array}$ & $\begin{array}{c}-0.023 \\
(-0.27)\end{array}$ & & & & & & & \\
\hline German legal origin & $\begin{array}{c}-0.178^{c} \\
(-3.19)\end{array}$ & $\begin{array}{c}-0.198^{c} \\
(-3.58)\end{array}$ & $\begin{array}{c}-0.204^{\mathrm{c}} \\
(-3.68)\end{array}$ & & & & & & & \\
\hline Scandinavian legal origin & $\begin{array}{c}-0.113 \\
(-1.51)\end{array}$ & $\begin{array}{r}-0.166^{\mathbf{b}} \\
(-2.19)\end{array}$ & $\begin{array}{r}-0.145^{\mathrm{a}} \\
(-1.95)\end{array}$ & & & & & & & \\
\hline Socialist legal origin & $\begin{array}{r}0.688^{\mathrm{C}} \\
(3.39)\end{array}$ & $\begin{array}{c}0.577^{\mathbf{b}} \\
(2.41)\end{array}$ & $\begin{array}{r}0.695^{\mathbf{c}} \\
(2.69)\end{array}$ & & & & & & & \\
\hline Political rights & $\begin{array}{c}-0.190^{c} \\
(-7.42)\end{array}$ & $\begin{array}{c}-0.117^{\mathbf{a}} \\
(-1.84)\end{array}$ & & & & $\begin{array}{c}-0.124 \\
(-1.54)\end{array}$ & & $\begin{array}{c}-0.211^{\mathrm{c}} \\
(-7.98)\end{array}$ & $\begin{array}{c}-0.133^{\mathrm{a}} \\
(-1.96)\end{array}$ & \\
\hline Democracy & & & & $\begin{array}{c}-0.112^{c} \\
(-8.47)\end{array}$ & $\begin{array}{c}-0.032^{\mathbf{b}} \\
(-1.99)\end{array}$ & & & & & \\
\hline SPI & & $\begin{array}{l}0.026 \\
(0.60)\end{array}$ & $\begin{array}{l}0.002 \\
(0.052)\end{array}$ & & $\begin{array}{c}0.016 \\
(0.45)\end{array}$ & & & & $\begin{array}{c}0.071^{\mathrm{a}} \\
(1.82)\end{array}$ & $\begin{array}{c}0.038 \\
(1.08)\end{array}$ \\
\hline SPI AP & & & & & & $\begin{array}{c}0.023^{\mathrm{c}} \\
(4.01)\end{array}$ & $\begin{array}{r}0.022^{\mathrm{c}} \\
(3.89)\end{array}$ & & & \\
\hline Freedom of the press & & $\begin{array}{c}-0.010 \\
(-0.23)\end{array}$ & $\begin{array}{r}-0.068^{\mathrm{C}} \\
(-2.72)\end{array}$ & & $\begin{array}{c}-0.064^{\mathbf{b}} \\
(-2.32)\end{array}$ & $\begin{array}{c}0.000 \\
(0.0086)\end{array}$ & $\begin{array}{c}-0.034 \\
(-1.06)\end{array}$ & & $\begin{array}{l}0.008 \\
(0.19)\end{array}$ & $\begin{array}{r}-0.062^{b} \\
(-2.41)\end{array}$ \\
\hline Corruption & & $\begin{array}{c}0.144^{c} \\
(6.12)\end{array}$ & $\begin{array}{c}0.145^{\mathrm{c}} \\
(6.19)\end{array}$ & & $\begin{array}{c}0.134^{\mathrm{c}} \\
(5.82)\end{array}$ & $\begin{array}{c}0.136^{\mathrm{c}} \\
(5.59)\end{array}$ & $\begin{array}{c}0.137^{\mathrm{c}} \\
(5.66)\end{array}$ & & $\begin{array}{c}0.101^{\mathrm{c}} \\
(4.03)\end{array}$ & $\begin{array}{c}0.102^{\mathrm{C}} \\
(4.05)\end{array}$ \\
\hline Expropriation risk & & $\begin{array}{c}0.307^{c} \\
(4.62)\end{array}$ & $\begin{array}{c}0.328^{c} \\
(4.80)\end{array}$ & & $\begin{array}{c}0.224^{\mathbf{b}} \\
(2.56)\end{array}$ & $\begin{array}{c}0.186^{\mathbf{b}} \\
(2.17)\end{array}$ & $\begin{array}{c}0.226^{\mathrm{c}} \\
(2.77)\end{array}$ & & $\begin{array}{c}0.331^{\mathrm{c}} \\
(4.02)\end{array}$ & $\begin{array}{c}0.357^{c} \\
(4.19)\end{array}$ \\
\hline Creditor rights & $\begin{array}{c}-0.051^{\mathbf{b}} \\
(-2.25)\end{array}$ & $\begin{array}{c}-0.065^{\mathrm{c}} \\
(-2.68)\end{array}$ & $\begin{array}{c}-0.062^{\mathrm{c}} \\
(-2.59)\end{array}$ & $\begin{array}{c}-0.069^{c} \\
(-3.46)\end{array}$ & $\begin{array}{c}-0.087^{c} \\
(-4.33)\end{array}$ & $\begin{array}{c}-0.090^{\mathrm{c}} \\
(-4.74)\end{array}$ & $\begin{array}{c}-0.090^{\mathrm{c}} \\
(-4.70)\end{array}$ & $\begin{array}{c}-0.091^{\mathrm{c}} \\
(-3.73)\end{array}$ & $\begin{array}{r}-0.072^{\mathrm{c}} \\
(-3.09)\end{array}$ & $\begin{array}{r}-0.062^{c} \\
(-2.82)\end{array}$ \\
\hline Sovereign rating & $\begin{array}{c}-0.069^{c} \\
(-4.30)\end{array}$ & & & $\begin{array}{c}-0.056^{\mathbf{c}} \\
(-3.35)\end{array}$ & & & & $\begin{array}{c}-0.054^{\mathrm{c}} \\
(-3.10)\end{array}$ & & \\
\hline Cross-list & & & & & & & & $\begin{array}{l}0.052 \\
(0.99) \\
\end{array}$ & $\begin{array}{l}0.086 \\
(1.55) \\
\end{array}$ & $\begin{array}{l}0.076 \\
(1.39) \\
\end{array}$ \\
\hline Observations & 2,017 & 1,973 & 1,973 & 1,997 & 1,973 & 1,861 & 1,861 & 1,311 & 1,267 & 1,267 \\
\hline Adjusted R-squared & 0.588 & 0.587 & 0.587 & 0.580 & 0.585 & 0.576 & 0.576 & 0.569 & 0.565 & 0.565 \\
\hline Log Likelihood & $-2,258$ & $-2,200$ & $-2,201$ & $-2,247$ & $-2,207$ & $-2,076$ & $-2,076$ & $-1,440$ & $-1,384$ & $-1,384$ \\
\hline Unreported variables & n, $\mathrm{Ce}$ & $\begin{array}{l}\text { Log } \\
\text { Resi }\end{array}$ & $\begin{array}{l}\text { ets, } \mathrm{N} \\
\text { bond }\end{array}$ & $\begin{array}{l}\text { MTBV } \\
\text { Year }\end{array}$ & $\begin{array}{l}\text { ing, RO } \\
\text { ies, Ind }\end{array}$ & $\begin{array}{l}\text { everage, } \\
\text { dummi }\end{array}$ & bond & Floatir & d, Call & Putable, \\
\hline
\end{tabular}


Table IX

\section{Robustness tests with alternative sample}

The table presents robustness tests using Yankee bonds as an alternative sample. Columns (1)-(3) show regression results for bond rating, and columns (4)-(8) report regression estimates for log yield spread. The variable political rights $\times$ creditor rights is the residuals from regressing the interaction between political rights and creditor rights on its individual variables. All variables are described in Table I. The sample period is 1980 to 2006 . The models are estimated with OLS and include year and two-digit industry dummy variables (not reported). Standard errors are robust and corrected for clustering by firm; the associated tstatistics are reported in parenthesis. a, b, and c denote significance at the $10 \%, 5 \%$, and $1 \%$ levels, respectively.

\begin{tabular}{|c|c|c|c|c|c|c|c|c|}
\hline \multirow[t]{3}{*}{ Independent variables } & \multirow{2}{*}{\multicolumn{3}{|c|}{$\begin{array}{c}\text { Dependent variable: Bond rating } \\
\text { Replication of specifications (2), (3), and } \\
\text { (5) in Table VI }\end{array}$}} & \multicolumn{5}{|c|}{ Dependent variable: Log yield spread } \\
\hline & & & & \multicolumn{3}{|c|}{$\begin{array}{l}\text { Replication of specifications (2), (3), and } \\
\text { (5) in Table VII }\end{array}$} & \multicolumn{2}{|c|}{$\begin{array}{c}\text { Replication of } \\
\text { specifications (8) and (10) } \\
\text { in Table VIII }\end{array}$} \\
\hline & (1) & $(2)$ & (3) & (4) & (5) & (6) & (7) & (8) \\
\hline Political rights & $\begin{array}{c}0.488^{\mathrm{C}} \\
(3.23)\end{array}$ & $\begin{array}{c}0.613^{\mathrm{C}} \\
(4.21)\end{array}$ & & $\begin{array}{c}-0.163^{\mathrm{c}} \\
(-8.70)\end{array}$ & $\begin{array}{c}-0.186^{\mathrm{c}} \\
(-8.85)\end{array}$ & & $\begin{array}{c}-0.167^{\mathrm{C}} \\
(-8.90)\end{array}$ & \\
\hline SPI & & & $\begin{array}{c}0.454^{\mathrm{a}} \\
(1.90)\end{array}$ & & & $\begin{array}{r}-0.088^{b} \\
(-2.57)\end{array}$ & & $\begin{array}{r}-0.072^{\mathbf{b}} \\
(-2.12)\end{array}$ \\
\hline Freedom of the press & & & $\begin{array}{r}0.390^{\mathbf{b}} \\
(2.27)\end{array}$ & & & $\begin{array}{r}-0.093^{c} \\
(-4.41)\end{array}$ & & $\begin{array}{r}-0.090^{c} \\
(-4.25)\end{array}$ \\
\hline Corruption & & & $\begin{array}{c}0.044 \\
(0.22)\end{array}$ & & & $\begin{array}{l}0.021 \\
(1.01)\end{array}$ & & $\begin{array}{l}0.023 \\
(1.05)\end{array}$ \\
\hline Expropriation risk & & & $\begin{array}{r}-0.699^{b} \\
(-2.00)\end{array}$ & & & $\begin{array}{c}0.141^{\mathrm{c}} \\
(2.95)\end{array}$ & & $\begin{array}{r}0.148^{\mathrm{c}} \\
(3.04)\end{array}$ \\
\hline Creditor rights & $\begin{array}{c}0.502^{c} \\
(3.78)\end{array}$ & $\begin{array}{c}0.549^{c} \\
(4.18)\end{array}$ & $\begin{array}{c}0.415^{\mathrm{c}} \\
(2.96)\end{array}$ & $\begin{array}{c}-0.128^{c} \\
(-8.32)\end{array}$ & $\begin{array}{c}-0.138^{c} \\
(-9.13)\end{array}$ & $\begin{array}{c}-0.106^{\mathbf{c}} \\
(-5.84)\end{array}$ & $\begin{array}{c}-0.118^{\mathrm{c}} \\
(-7.50)\end{array}$ & $\begin{array}{c}-0.097^{\mathrm{c}} \\
(-5.31)\end{array}$ \\
\hline Political rights $\times$ Creditor rights & & $\begin{array}{c}-0.095 \\
(-1.01)\end{array}$ & & & $\begin{array}{r}0.034^{\mathrm{c}} \\
(2.62)\end{array}$ & & & \\
\hline Sovereign rating & $\begin{array}{l}0.176 \\
(1.57)\end{array}$ & & & $\begin{array}{c}-0.031^{\mathrm{c}} \\
(-2.87)\end{array}$ & & & $\begin{array}{c}-0.030^{\mathrm{c}} \\
(-2.75)\end{array}$ & \\
\hline Cross-list & & & & & & & $\begin{array}{r}-0.142^{c} \\
(-3.22) \\
\end{array}$ & $\begin{array}{c}-0.157^{\mathrm{c}} \\
(-3.58) \\
\end{array}$ \\
\hline Observations & 1,073 & 1,076 & 1,047 & 920 & 922 & 898 & 920 & 898 \\
\hline Adjusted R-squared & 0.598 & 0.595 & 0.599 & 0.772 & 0.770 & 0.769 & 0.771 & 0.769 \\
\hline Log Likelihood & $-2,475$ & $-2,486$ & $-2,412$ & -422.2 & -425.8 & -417.2 & -422.2 & -417.1 \\
\hline
\end{tabular}


Table X

\section{Fixed effects regressions}

This table shows firm fixed effects regression estimates for the log yield spread on political and legal variables, firm controls, and bond characteristics. Columns (1)-(3) report results for Eurobonds, and columns (4)-(6) show results for Yankee bonds. All variables are described in Table I. The sample period is 1980 to 2006. The models are estimated with firm fixed effects and include year dummies (not reported). Standard errors are robust and corrected for clustering by firm; the associated t-statistics are reported in parentheses. a, b, and c denote significance at the $10 \%, 5 \%$, and $1 \%$ levels, respectively.

\begin{tabular}{|c|c|c|c|c|c|c|}
\hline \multirow[t]{3}{*}{ Independent variables } & \multicolumn{3}{|c|}{ Eurobonds } & \multicolumn{3}{|c|}{ Yankee bonds } \\
\hline & \multicolumn{3}{|c|}{ Dependent variable: Log yield spread } & \multicolumn{3}{|c|}{ Dependent variable: Log yield spread } \\
\hline & $(1)$ & $(2)$ & (3) & (4) & $(5)$ & (6) \\
\hline Political rights & $\begin{array}{c}-0.397^{\mathrm{c}} \\
(-3.29)\end{array}$ & $\begin{array}{c}-0.448^{\mathrm{b}} \\
(-2.56)\end{array}$ & & $\begin{array}{l}-0.091^{\mathrm{b}} \\
(-1.98)\end{array}$ & $\begin{array}{c}-0.188 \\
(-0.89)\end{array}$ & \\
\hline Socio-political instability & & $\begin{array}{c}0.032 \\
(0.13)\end{array}$ & $\begin{array}{l}0.019 \\
(0.075)\end{array}$ & & $\begin{array}{c}-0.087 \\
(-0.36)\end{array}$ & $\begin{array}{c}-0.128 \\
(-0.55)\end{array}$ \\
\hline Freedom of the press & & $\begin{array}{l}0.062 \\
(0.62)\end{array}$ & $\begin{array}{l}-0.010 \\
(-0.098)\end{array}$ & & $\begin{array}{r}-0.219^{b} \\
(-2.31)\end{array}$ & $\begin{array}{c}-0.301^{\mathrm{C}} \\
(-3.22)\end{array}$ \\
\hline Corruption & & $\begin{array}{r}0.123^{b} \\
(2.56)\end{array}$ & $\begin{array}{r}0.135^{\mathrm{c}} \\
(2.94)\end{array}$ & & $\begin{array}{c}-0.022 \\
(-0.31)\end{array}$ & $\begin{array}{r}-0.012 \\
(-0.18)\end{array}$ \\
\hline Expropriation risk & & $\begin{array}{c}0.000 \\
(-)\end{array}$ & $\begin{array}{c}0.000 \\
(-)\end{array}$ & & $\begin{array}{c}0.000 \\
(-)\end{array}$ & $\begin{array}{c}0.000 \\
(-)\end{array}$ \\
\hline Creditor rights & $\begin{array}{c}-0.063 \\
(-0.36)\end{array}$ & $\begin{array}{c}-0.053 \\
(-0.28)\end{array}$ & $\begin{array}{c}-0.029 \\
(-0.16)\end{array}$ & $\begin{array}{c}-0.138 \\
(-1.09)\end{array}$ & $\begin{array}{c}-0.150 \\
(-1.16)\end{array}$ & $\begin{array}{c}-0.134 \\
(-1.03)\end{array}$ \\
\hline Observations & 1,783 & 1,753 & 1,753 & 761 & 743 & 743 \\
\hline Number of firms groups & 286 & 280 & 280 & 182 & 178 & 178 \\
\hline $\begin{array}{l}\text { Average number of observations } \\
\text { per firm group }\end{array}$ & 6.234 & 6.261 & 6.261 & 4.181 & 4.174 & 4.174 \\
\hline Adjusted R-squared & 0.262 & 0.270 & 0.268 & 0.549 & 0.549 & 0.549 \\
\hline Log Likelihood & $-1,810$ & $-1,768$ & $-1,771$ & -196.0 & -190.9 & -191.0 \\
\hline
\end{tabular}


Table XI

Robustness tests with orthogonalized political variables

The table shows regression estimates for bond rating and log yield spreads on political and legal conditions, firm controls, and bond characteristics. Columns (1)-(4) report results for Eurobonds, columns (5)-(8) show results for Yankee bonds. All political variables are orthogonal to each other and are identified by the symbol $\perp$. We use a modified Gram-Schmidt orthogonalization approach described in Golub and Van Loan (1996) to orthogonalize the political variables. The order of the variables in that process is political rights, socio-political instability, freedom of the press, corruption, and expropriation risk. All variables are described in Table I. The sample period is 1980 to 2006. The models are estimated with OLS and include year and two-digit industry dummies (not reported). Standard errors are robust and corrected for clustering by firm; the associated t-statistics are reported in parentheses. a, b, and c denote significance at the 10\%, $5 \%$, and $1 \%$ levels, respectively.

\begin{tabular}{|c|c|c|c|c|c|c|c|c|}
\hline \multirow[t]{3}{*}{ Independent variables } & \multicolumn{4}{|c|}{ Eurobonds } & \multicolumn{4}{|c|}{ Yankee bonds } \\
\hline & \multicolumn{2}{|c|}{$\begin{array}{c}\text { Dependent variable: } \\
\text { Bond rating }\end{array}$} & \multicolumn{2}{|c|}{$\begin{array}{c}\text { Dependent variable: } \\
\text { Log yield spread } \\
\end{array}$} & \multicolumn{2}{|c|}{$\begin{array}{c}\text { Dependent variable: } \\
\text { Bond rating } \\
\end{array}$} & \multicolumn{2}{|c|}{$\begin{array}{c}\text { Dependent variable: } \\
\text { Log yield spread }\end{array}$} \\
\hline & $(1)$ & $(2)$ & (3) & (4) & (5) & (6) & (7) & (8) \\
\hline Political rights $\perp$ & $\begin{array}{l}0.582^{c} \\
(3.09)\end{array}$ & & $\begin{array}{r}-0.263^{c} \\
(-8.18)\end{array}$ & & $\begin{array}{c}0.529^{\mathbf{b}} \\
(2.42)\end{array}$ & & $\begin{array}{c}-0.148^{c} \\
(-6.12)\end{array}$ & \\
\hline Socio-political instability $\perp$ & $\begin{array}{l}-0.282^{b} \\
(-2.26)\end{array}$ & $\begin{array}{c}-0.377^{\mathbf{b}} \\
(-2.38)\end{array}$ & $\begin{array}{c}0.158^{\mathrm{c}} \\
(6.27)\end{array}$ & $\begin{array}{c}0.207^{\mathrm{c}} \\
(7.05)\end{array}$ & $\begin{array}{l}0.031 \\
(0.20)\end{array}$ & $\begin{array}{l}-0.065 \\
(-0.36)\end{array}$ & $\begin{array}{l}0.015 \\
(0.65)\end{array}$ & $\begin{array}{l}0.040 \\
(1.54)\end{array}$ \\
\hline Freedom of the press $\perp$ & $\begin{array}{c}0.136 \\
(1.11)\end{array}$ & $\begin{array}{c}0.470^{\mathbf{b}} \\
(2.47)\end{array}$ & $\begin{array}{r}-0.053^{b} \\
(-2.40)\end{array}$ & $\begin{array}{l}-0.207^{c} \\
(-7.77)\end{array}$ & $\begin{array}{l}0.097 \\
(0.65)\end{array}$ & $\begin{array}{r}0.505^{\mathbf{b}} \\
(2.45)\end{array}$ & $\begin{array}{l}0.001 \\
(0.053)\end{array}$ & $\begin{array}{l}-0.127^{\mathrm{c}} \\
(-5.57)\end{array}$ \\
\hline Corruption $\perp$ & $\begin{array}{r}-0.448^{c} \\
(-3.30)\end{array}$ & $\begin{array}{r}-0.463^{c} \\
(-3.27)\end{array}$ & $\begin{array}{c}0.184^{\mathrm{c}} \\
(7.44)\end{array}$ & $\begin{array}{c}0.197^{\mathrm{c}} \\
(7.73)\end{array}$ & $\begin{array}{c}-0.075 \\
(-0.30)\end{array}$ & $\begin{array}{c}-0.124 \\
(-0.49)\end{array}$ & $\begin{array}{l}0.039 \\
(1.57)\end{array}$ & $\begin{array}{c}0.058^{\mathbf{b}} \\
(2.32)\end{array}$ \\
\hline Expropriation risk $\perp$ & $\begin{array}{c}0.041 \\
(0.36)\end{array}$ & $\begin{array}{c}0.024 \\
(0.20)\end{array}$ & $\begin{array}{c}0.078^{\mathbf{C}} \\
(3.36)\end{array}$ & $\begin{array}{c}0.090^{\mathrm{C}} \\
(3.58)\end{array}$ & $\begin{array}{c}-0.227^{\mathrm{a}} \\
(-1.68)\end{array}$ & $\begin{array}{c}-0.270^{\mathbf{b}} \\
(-2.00)\end{array}$ & $\begin{array}{c}0.038^{\mathbf{b}} \\
(2.10)\end{array}$ & $\begin{array}{c}0.054^{\mathrm{C}} \\
(2.95)\end{array}$ \\
\hline Creditor rights & $\begin{array}{r}0.521^{\mathrm{c}} \\
(5.33) \\
\end{array}$ & $\begin{array}{r}0.508^{\mathbf{c}} \\
(5.27) \\
\end{array}$ & $\begin{array}{r}-0.098^{\mathrm{c}} \\
(-4.95) \\
\end{array}$ & $\begin{array}{r}-0.093^{\mathrm{c}} \\
(-4.85) \\
\end{array}$ & $\begin{array}{r}0.457^{\mathrm{c}} \\
(2.96) \\
\end{array}$ & $\begin{array}{r}0.416^{\mathbf{c}} \\
(2.96) \\
\end{array}$ & $\begin{array}{r}-0.124^{\mathrm{c}} \\
(-6.50) \\
\end{array}$ & $\begin{array}{r}-0.106^{\mathrm{c}} \\
(-5.84) \\
\end{array}$ \\
\hline Observations & 2,450 & 2,450 & 1,973 & 1,973 & 1,046 & 1,046 & 898 & 898 \\
\hline Adjusted R-squared & 0.582 & 0.581 & 0.585 & 0.585 & 0.600 & 0.599 & 0.769 & 0.769 \\
\hline Log Likelihood & $-5,443$ & $-5,448$ & $-2,206$ & $-2,207$ & $-2,408$ & $-2,409$ & -415.9 & -417.2 \\
\hline Unreported variables & $\begin{array}{l}\text { er capit } \\
\text { Lonvexit }\end{array}$ & $\begin{array}{l}\text { otal asset } \\
\text { duals of b }\end{array}$ & $\begin{array}{l}\text { BV, MTB } \\
\text { ting, Yeal }\end{array}$ & $\begin{array}{l}\text { ing, ROA } \\
\text { hies, Indu }\end{array}$ & $\begin{array}{l}\text { rage, Pub } \\
\text { mmies }\end{array}$ & id issue, $\mathrm{F}$ & bond, $\mathrm{C}$ & Putable, \\
\hline
\end{tabular}




\section{Appendix A \\ Bond rating numerical conversions}

This table provides bond rating conversion codes for S\&P ratings used in the analysis. S\&P ratings of 13 and above are considered investment grade, while those below 13 are non-investment grade.

\begin{tabular}{cc}
\hline S\&P ratings & Conversion number \\
\hline AAA & 21 \\
AA+ & 20 \\
AA & 19 \\
AA- & 18 \\
A+ & 17 \\
A & 16 \\
A- & 15 \\
BBB + & 14 \\
BBB & 13 \\
BBB- & 12 \\
BB+ & 11 \\
BB & 10 \\
BB- & 9 \\
B+ & 8 \\
B & 7 \\
B- & 6 \\
CCC + & 5 \\
CCC & CC- \\
CC & 4 \\
C & 3 \\
\end{tabular}




\section{Appendix B \\ Comprehensive credit rating}

Following Gande and Parsley (2007) we code S\&P sovereign credit ratings using the following chart. The reported credit rating is assigned a numerical code from 0 through 21 as indicated to obtain the explicit credit rating (ECR). Next, we add the reported information on the credit outlook (OL), coded from -1 to +1 , to obtain the comprehensive credit rating (CCR), i.e., CCR = ECR + OL. For example, if a country is rated BB+ with stable credit outlook, its ECR and CCR are 11. If S\&P revises the outlook to credit watch-negative (from stable), the ECR remains 11. However, its CCR is 10.50 .

\begin{tabular}{cccc}
\hline \multicolumn{2}{c}{ Explicit credit rating (ECR) } & \multicolumn{2}{c}{ Credit Outlook (CO) } \\
Sovereign rating & Conversion number & Outlook & Conversion number \\
\hline AAA & 21 & Positive & 1 \\
AA+ & 20 & Credit Watch-Developing & 0.5 \\
AA & 19 & Ctable & 0 \\
AA- & 18 & Credit Watch-Negative & -0.5 \\
A+ & 17 & & -1 \\
A & 16 & \\
A- & 15 & \\
BBB+ & 14 & \\
BBB & 13 & \\
BBB- & 12 & \\
BB + & 11 & \\
BB & 10 & \\
BB- & 9 & \\
B+ & 8 & \\
B & 7 & \\
B- & 6 & \\
CCC+ & 5 & \\
CCC & 4 & \\
CCC- & 3 & \\
CC & 2 & \\
C & 1 & \\
SD, D & 0 & \\
& & \\
\end{tabular}

